\title{
The Impact of Fiscal Policy on Profits
}

\author{
Margarita Katsimi \\ Vassilis Sarantides
}

CESifo Working PAPER No. 2849

CATEgory 1: Public FinANCE

NOVEMBER 2009

\footnotetext{
An electronic version of the paper may be downloaded

- from the SSRN website: www.SSRN.com

- from the RePEc website:

- from the CESifo website: 


\title{
The Impact of Fiscal Policy on Profits
}

\begin{abstract}
This paper investigates the impact of fiscal policy on profits using panel data for 19 highincome OECD countries during the period 1975-1999. We estimate a profit equation in which profits depend on a set of fiscal variables. Our empirical method is based on a consistent treatment of the government budget constraint, and we try to disentangle the effects of different spending and taxation items. As far as public spending is concerned, our results strongly suggest that capital expenditures are associated with higher profits, while expenditures on wages and salaries deteriorate profits. At the same time our results indicate that transport and communication expenditures increase profits, while the opposite holds for defense expenditures. On the revenue side, both direct and indirect taxation tend to decrease profits. However, a more detailed sub-division of direct taxation indicates that social security contributions have a neutral effect on profits.
\end{abstract}

JEL Code: E62, H32, H54.

Keywords: fiscal policy, profits, quality of public expenditure.

\author{
Margarita Katsimi \\ Athens University of Economics and \\ Business \\ Department of International and European \\ Economic Studies \\ Patision Str 76 \\ Greece - Athens 10434 \\ mkatsimi@aueb.gr
}

\author{
Vassilis Sarantides \\ Athens University of Economics and \\ Business \\ Patision Str 76 \\ Athens 10434 \\ Greece \\ sarantides@aueb.gr
}

October 2009

Without implicating, we wish to thank Sarantis Kalyvitis, Thomas Moutos and seminar participants at the Athens University of Economics and Business for useful comments and suggestions. 


\section{Introduction}

A large number of policy-making decisions rely on the key macroeconomic question of the nature of fiscal policy's impact on the economy. Therefore, it is not surprising that the impact of fiscal policy on macroeconomic aggregates has been extensively studied in the empirical literature. ${ }^{1}$ However, some of the transmission channels between fiscal policy and the macroeconomic aggregates have not been thoroughly investigated; the one relatively under-investigated channel that is the subject of the present paper is the effect of fiscal policy on profits.

The role of profits as a key driving force of capital accumulation and economic activity has been of paramount importance in economic thinking since the time of Adam Smith and David Ricardo. More recently, Abel and Blanchard (1986), Phelps (1994), Alesina et al. (2002) and Garcia-Penalosa and Turnovsky (2007) have provided models in which profits play a central role as a determinant of investment and growth. Given the importance of profits in shaping macroeconomic developments, it is surprising that - to the best of our knowledge - the only existing empirical study that investigates the influence of fiscal policy on business profits is the one by Alesina et al. (2002).

The purpose of this paper is to examine the relation between fiscal policy and profits. Our approach is novel in the following two aspects. First, following KnellerBleaney-Gemmel $(1999,2001)$ (hereafter KBG) our empirical method is based on a full specification of the government budget constraint. KBG outline - their method is explained in the following section - that incomplete specification of the budget constraint results in substantial biases in parameter estimates. Additionally, KBG sub-divide the government budget constraint in a way that allows us to take into account the quality of fiscal policy. On a panel of 22 high-income OECD countries over the period 1970-95 they find that an increase in 'productive expenditures' has a growth enhancing effect, while 'distortionary' taxation hampers economic growth.

Second, although, for reasons discussed in the next section, our empirical analysis is orientated mainly towards the economic classification of expenditures we also

\footnotetext{
${ }^{1}$ For the "Keynesian" and "non-Keynesian" impact of fiscal policy see Beetsma (2008) and Hemming et al. (2000). Blanchard and Perotti (2002), Perotti (2005) and Fatas and Mihov (2001) find empirical results that support the Keynesian view of a positive government spending effect on consumption, while Burnside et al. (2003) find evidence for the RBC model's prediction of a negative government spending effect on consumption. For a review of studies that investigate the impact of taxation on the cost of capital see Hassett and Hubbard (1996) and Chirinko (1993).
} 
investigate the effect of the functional components of public spending on profits. $^{2}$ According to the Government Finance Statistics of IMF, government expenditures can be classified along two main lines. The economic classification that divides public spending into capital and current expenditures and the functional classification that serves to distinguish transactions by policy purpose or type of outlay. Some broad categories of the functional classification are transport and communication and healthcare expenditures, each of which includes current and capital expenditures.

We focus our study on 19 high-income OECD countries over the period 19751999. Regarding the economic classification of public spending, results clearly indicate that capital expenditures have a positive impact on profits, while the coefficient on current expenditures is statistically insignificant. Even so, when we disaggregate current expenditures we find that wages and salaries expenditures deteriorate profits, while nonwage expenditures have a positive impact on profits. As for the functional components of public spending our results suggest that transport and communication expenditures increase profits, while the opposite holds for defense expenditures. As far as tax variables are concerned, direct and indirect taxation seem to decrease profits. However, a more detailed sub-division of direct taxation indicates that social security contributions have a neutral effect on profits.

The remainder of the paper is organized as follows. Section 2 discusses the data, specifies the econometric model and contains our basic findings. Section 3 then reports the results of extensive robustness tests. The last section concludes.

\section{Empirical analysis}

\subsection{Fiscal data}

Our fiscal data are obtained from the Global Development Network Growth Database complied by William Easterly. Primary data for the proceeds are taken from Government Finance Statistics - an annual edition of the International Monetary Fund; and the data

\footnotetext{
${ }^{2}$ This is the reason for using Global Development Network Growth Database, instead of OECD Economic Outlook database. The latter includes the functional classification of expenditures, but for a much shorter time span. At the same time, these databases are not comparable, since the former refers to central government accounts while the latter on general government accounts.
} 
for GDP from Global Development Finance and World Bank's 'World Development Indicators'. We choose this database since, to the best of our knowledge, it is the most complete database for fiscal elements that compose public spending (economic and functional classification) and revenues (see Appendix for details on data sources and descriptive statistics).

As far as the quality of fiscal policy is concerned, following Aschauer (1989) and Devarajan et al. (1996), the literature dealing with the growth impact of fiscal policy recognized that one should make a distinction between 'productive' and 'unproductive' public spending. In general, government expenditure components are classified as productive, if they are included as arguments in the private production function and as unproductive if they are not. Similarly, taxation items can be classified either as direct (distortionary) taxation, if they affect the investment decisions of individuals or as indirect (non-distortionary) taxation if they do not affect the saving/investment decision [see among others Barro (1990), KBG and Mendoza (1997)]. Given that allowing for a disaggregation of the government budget constraint along these lines seems to be a promising way forward in the empirical literature on fiscal policy and growth and despite the fact that the classification of certain budget items can be debatable, we try -as much as data availability allows us- to adopt this approach in our analysis. Although, we do not use the a priori classification of government expenditures as 'productive' and 'unproductive' as in KBG, we let the data 'do the talking' [see among others Devarajan et al. (1996), Bose et al. (2007), Gosh and Georgiou (2008)].

Turning to the classification of fiscal data, we sub-divide public spending into capital expenditures and current expenditures. This is our basic classification. Although, later on we examine if any sub-component of current expenditures have an impact on profits, while, alternatively, we experiment with the functional classification of public spending. On the revenue side, we classify revenue as direct (distortionary) taxation, indirect (non-distortionary) taxation and other revenues (as in $\mathrm{KBG}$ ). ${ }^{3}$ Direct taxation includes taxation on income and profits, social security contributions, taxation on payroll and manpower and taxation on property, while indirect taxation consists of taxation on

\footnotetext{
${ }^{3}$ We consider taxation on international trade as a form of indirect taxation sine taxes on international trade and transactions in the OECD countries consist mainly of import and export duties.
} 
goods and services and taxation on international trade. Additionally, other revenues contain non-tax revenues and other tax revenues (not elsewhere classified). Finally, in our regressions we include the budget surplus (deficit). ${ }^{4}$ All fiscal variables are expressed as a percentage of GDP.

Given that, as mentioned in the introduction, our empirical method is based on a full specification of the government budget constraint we will next refer shortly to the relevant argument presented in $\mathrm{KBG} .^{5}$ Let is initially suppose that we want to include in our empirical analysis all the elements of the budget constraint. In order to avoid perfect multi-collinearity one element should be omitted. At the same time, suppose that we choose to omit from our specification fiscal element $X_{m}$ with estimated coefficient $\gamma_{m}$. This implies that the estimated coefficient $\gamma_{j}$ for another fiscal element $\mathrm{X}_{\mathrm{j}}$, which we include in the estimated equation, will now equal $\left(\gamma_{j}-\gamma_{m}\right)$. Consequently, the standard hypothesis test of zero coefficient for the fiscal element $X_{j}$ is in fact testing the hypothesis $\left(\gamma_{j}-\gamma_{m}\right)=0$ rather than $\gamma_{j}=0$. Therefore, if we want to get unbiased estimates for all fiscal elements, we should exclude from the regression fiscal variables with negligible effect on profits $\left(\gamma_{m}=0\right)$. Regarding the interpretation of results, coefficient $\gamma_{j}$ measures the marginal impact of fiscal variable $X_{j}$ on profits, net of the marginal impact of fiscal variable $X_{m}$, which is the assumed implicit financing element.

\subsection{The profit equation}

The empirical literature on the determinants of profits is mainly concentrated in identifying the determinants of sectoral rather than aggregate profits. A relatively large literature has attempted to identify the determinants of profits at the sectoral level using measures of the market value or accounting profits [see among others Schmalensee (1989), McGahan and Porter (2002)]. The determinants include firm-specific characteristics as well as market structure and industry-specific characteristics. On the

\footnotetext{
${ }^{4}$ Overall budget surplus is total revenues and official grants received, less total expenditure and lending minus repayments. It is worth noting, that in our regressions we do not include the very small components grants for the side of revenues and lending minus repayments for the side of expenditures. This happens for two reasons, first, because these elements reduce our sample significantly and second because when we include them in regressions, they turn out to be insignificantly related with profits.

${ }^{5}$ For details see pp. $174-175$ of their paper.
} 
other hand, the existing literature on the determinants of aggregate profits is rather limited. Finkel and Tuttle (1971) have been the first who have attempted to identify empirically the determinants of aggregate corporate profit margin by using capacity utilization, unit labour cost, inflation and exports.

More recently Alesina et al. (2002) examined the effects of various fiscal variables on aggregate profits, proxied by gross profits per unit of capital in the business sector. On a panel of 18 high-income OECD countries from 1960-1996 they find that an increase in government spending and especially in government wage bill can reduce profits and investment. This effect takes place because an increase in the wage bill of the public sector leads to an increase in wages in the private sector and consequently reduces profits and investment. ${ }^{6}$ On the revenue side, labor taxation seems to have a sizeable negative effect on profits and investment. According to Alesina et al. (2002), an increase in labor taxes raises the cost of work relative to leisure, leading to a fall of labor supply and a reduction in profits and investment. It is worth noting that the effects of government spending on profits and investment are larger than those of taxation.

Our first concern is to choose an appropriate profits indicator for our dependent variable. The two main sources of profit data are national account and corporate account data. We use here national account data since they cover the whole economy and are more consistent across countries and time. The national account measure of profits is the gross operating surplus. ${ }^{7}$ Specifically, we measure profits as the gross operating surplus (\% GDP), defined as GDP less compensation of employees and taxes (minus subsidies) on production, denoted as profits and obtained from the Annual Macroeconomic database of the European Commission. The empirical model we estimate is of the following form:

$$
\text { PROFITS }_{i t}=\beta_{m} M_{i t}+\beta_{z} Z_{i t}+\mu_{t}+\lambda_{t}+\varepsilon_{i t}
$$

\footnotetext{
${ }^{6}$ See e.g., Finn (1998) for perfectly competitive labor markets and Ardagna (2007) for unionized labor markets.

${ }^{7}$ Generally, the measurement of profits at the macroeconomic level is subject to a high degree of uncertainty [see ECB Monthly Bulletin (2004)]. The net rate of return on capital can be an alternative measure of profits but its measurement of is affected by all the difficulties related to the calculation of the capital stock.
} 
where $\mathrm{M}$ is a set of fiscal variables, $\mathrm{Z}$ is the set of 'other' variables that we use to control for country-specific profits related characteristics. Finally, $\mu_{\mathrm{i}}$ and $\lambda_{\mathrm{i}}$ are country and time specific fixed effects and $\varepsilon_{i, t}$ is the error term.

Of course, the inclusion of country and time-specific effects gives us the advantage of controlling for a large part of omitted variable bias. On the other hand, one quite difficult task of this study is to find appropriate control variables for the model specification. This difficulty occurs because this is the first study that attempts to introduce a set of control variables among the regressors in an aggregate profit equation. In the only relevant paper, Alesina et al. (2002) use as control variables two lags of the dependent variable. Therefore, before including tax-spending variables in our model specification, we experiment with several control variables that intuitively are considered to be important for the determination of aggregate profits. The following control variables seem to have a significant effect on profits:

(a) An indicator of the development of labour cost relative to labour productivity. Instead of using a measure of unit labour cost we construct an excessive wage indicator that we borrow from Malley and Moutos (2006). We obtain the 'excessive wage' indicator by estimating the regression:

$$
\ln \left(W_{t}\right)=a_{0}+a_{1} \ln \left(P_{t}\right)+\eta_{t}
$$

for each country ${ }^{8}$ using annual data obtained from OECD Economic Outlook database (online version). In the estimated equation, $\mathrm{W}_{\mathrm{t}}$ is the real compensation per employee and $\mathrm{P}_{\mathrm{t}}$ is the productivity index. The residuals, $\eta_{t}$, estimated in this first step, are the excessive wage variable that we apply in the second step in equation (1). ${ }^{9}$ Pagan (1984) show that using residuals generated repressors in a two-step OLS approach, produce consistent and efficient estimators, while valid inferences can be made with the standard errors provided as output from the second step. Furthermore, both Pudney (1982) and Pagan (1984) argue

\footnotetext{
${ }^{8}$ Qualitative results remain unaffected, when we pool cross-sections in equation 2, allowing for country and time specific characteristics.

${ }^{9}$ Before estimating our model, we tested whether fiscal policy has an impact on excessive wage indicator. Our results did not show an effect of fiscal policy on the part of wages that cannot be explained by productivity. Moreover, given that excessive wage indicator is a generated regressor, for its construction we use the wider time range the database allows us for each country.
} 
that our results from equation (1) are consistent as long as $\operatorname{cov}(\varepsilon, \eta)=0$. We will examine the validity of this assumption in the next section using the Davidson and MacKinnon test of exogeneity.

(b) A measure of competitiveness. Our next control variable is the real effective exchange rate index (reer) extracted by deflating the nominal effective exchange rate with price indices. According to the definition of the International Monetary Found, the real effective exchange rate is computed as the weighted geometric average of the price of the domestic country relative to the prices of its trade partners. An increase in the index for each country indicates deterioration of competitiveness and vice versa. These data are from International Financial Statistics - an annual edition of the International Monetary Found (online version).

(c) The state of demand. As a measure of demand, we use the growth rate of final consumption (consumption), obtained from the World Bank's 'World Development Indicators' (online version).

(d) The unemployment rate. Unemployment may affect profits through its impact on nonwage labour cost. For example, the cost of searching for a workforce with the appropriate skills may depend on how "tight" the labour market is. These data are from $O E C D$ Economic Outlook (online version).

It is also worth mentioning, that we have attempted to employ in our model specification a series of other control variables. For instance, we included obvious candidates such as the real interest rate or the degree of openness of an economy. However, these additional control variables did not have a significant relationship with the profit share, while including them in our specification did not change our basic findings.

Our sample spans over the period 1975 to 1999 and includes 19 high-income OECD countries: Australia, Austria, Belgium, Canada, Denmark, Finland, France, Germany, Ireland, Italy, Japan, Netherlands, Norway, Portugal, Spain, Sweden, Switzerland, United Kingdom, United States. ${ }^{10}$ Given that profits depict a very high cyclicality, we follow the standard approach of constructing 5-year period averages (1975-79 to 1995-99) so as to minimize business cycle effects. Two small OECD

\footnotetext{
${ }^{10}$ Our choice of country and time period of our sample is restricted by the (un)availability of data.
} 
countries, Iceland and Luxemburg are excluded from the sample. At the same time New Zealand is dropped due to data unavailability. Finally, Greece has been excluded from the sample as an outlier. Although, there is no theoretical justification for dropping outliers from our sample, it would be of considerable concern if our results where driven by them. We have detected for the case of Greece that observations for variable profits are laying three standard deviations above the mean (three-sigma rule) ${ }^{11}$, while Hadi's (1992) method identifies them as outliers. ${ }^{12}$

\subsection{Empirical Strategy}

In this section we perform a variety of specification tests as proposed by modern econometric analysis for panel data. Results clearly indicate that two-way Fixed Effects specification is the most appropriate to estimate equation (1). We start by employing the Breusch and Pagan Lagrange Multiplier test (see test $\mathrm{N}_{1}$ in Tables 1-6) for random effects. The LM test is a test on the variance of the presence of country specific effects, with the null hypothesis indicating no unobserved heterogeneity $\left(\mu_{\mathrm{i}}=\mu\right.$ in eq.1) and the pooled OLS estimator as the most appropriate approach. For each model specification, the null hypothesis of no unit specific random effects cannot be accepted, which means that we cannot ignore the presence of country-specific effects.

Next, in order to check if between Fixed Effects model and Random Effects model one is superior to the other, the Hausman test $\left(\mathrm{N}_{2}\right)$ is performed. The null hypothesis of the Hausman test is that regressors and the unobservable country-specific random error are uncorrelated. As can be seen, the Hausman test clearly indicates the use of Fixed Effects model, while at the same time we cannot accept the joint insignificance of country-specific characteristics (Prob $>\mathrm{F}=0.000$ ). It is worth noting, that Fixed Effects are a reasonable way to proceed with panel data, as they always give consistent results, yet they may not be efficient. Baltagi (2005) argues that fixed effects model is an appropriate specification for panel data analysis, when focusing on a specific set of individuals, which fits in our case of 19 high-income OECD countries. It is also

\footnotetext{
${ }^{11}$ The estimated mean (std.dev.) for profits, for the countries we include in the sample is 37.169 (4.367), while Greece has an estimated mean (std.dev.) of 62.197 (2.04).

12 The Hadi (1992) method measures the distance of data points from the main body of data and then iteratively reduces the sample to exclude distant data points. We set the significance level for outlier cutoff at $\mathrm{p}=0.1$.
} 
important to check, with an F-test $\left(\mathrm{N}_{3}\right)$, whether time fixed effects should be included in our estimated model. Results strongly suggest the inclusion of time dummies in our regressions.

To continue with, one problem we face when we use the Fixed Effects estimator is the assumption that the regressors included in model specification are not correlated with the error term. In fact, averaging the data allows us to control for a large part of simultaneity in our regressions, while the inclusion of country and time-specific effects give us the advantage of controlling for a large part of omitted variable bias. Additionally, although, it is very difficult to find appropriate instruments for all fiscal variables, we implement Davidson and MacKinnon exogeneity test $\left(\mathrm{N}_{4}\right)$ for fixed effects panel or pooled data. A rejection of the null indicates that endogenous regressors effects on the estimates are meaningful. Our primary objective is to examine the exogeneity assumption for all fiscal variables and the excessive wage indicator. Therefore, initially we consider only tax-spending variables and the excessive wages as endogenous, but gradually we add in endogenous regressors all remaining control variables (except time dummies), without any qualitative difference for our results. Due to space considerations, we present the results when all explanatory variables are considered endogenous. We use as instruments the initial values for each 5 -year period average of our sample. As can be seen, results clearly indicate that any endogeneity among the regressors does not affect our estimates. ${ }^{13}$

Next, we want to check the statistical properties of our panel, although, we know that when the time length of the panel is small this task becomes particularly difficult. The first hypothesis to be tested is that errors have equal variance across units (homoskedasticity). For this reason our model is tested by performing a likelihood ratio test $\left(\mathrm{N}_{5}\right)$, as proposed by Green (2000), of the null hypothesis of homoscedasticity versus the alternative hypothesis of heteroskedasticity across groups. The null hypothesis is strongly rejected, indicating the presence of groupwise heteroskedasticity.

Second, our model is tested for serial correlation arising when error terms for one unit of one year correlate with those of the previous year as well as for contemporaneous

\footnotetext{
${ }^{13}$ We perform Davidson and MacKinnon test separately for the fiscal variables and the excessive wage indicator, yielding the same results.
} 
correlation implying that error terms for one country correlate with those of another country. Initially, we employ a test of serial correlation $\left(\mathrm{N}_{6}\right)$ in the idiosyncratic errors of a linear panel-data model, as discussed by Wooldridge (2002), which strongly suggests the presence of first order autocorrelation. On the other hand, we have insufficient observations to test for cross-sectional dependence. One possible solution would be to use Feasible GLS estimator, which corrects for contemporaneous correlation, panel heteroscedasticity, and unit specific serial correlation. Although our qualitative results are not affected, as argued by Beck and Katz (1995), the correction for contemporaneous correlation is problematic unless $\mathrm{T}$ is considerably larger than $\mathrm{N}$. Therefore, our estimations include robust standard errors to both heteroskedasticity (Huber-White sandwich estimators) and any form of intra-cluster serial correlation. Since the clusters are countries in our case, this option corrects for intra-country serial correlation.

Finally, an alternative specification of our model would be to include a lagged dependent variable among the regressors in equation (1). Indeed, we employ the difference-generalized method of moments (GMM) methodology (Arellano-Bond (1991)), but we find insignificant coefficient for the lagged dependent variable. ${ }^{14}$ Moreover, these dynamic estimators are designed for large $\mathrm{N}$ and small $\mathrm{T}$ panels, which in our case can lead to severely biased and imprecise estimates. Therefore, although we opt for excluding the lagged dependent variable we believe that our model is properly specified since on the one hand, we take 5-year averages, including time fixed effects and on the other hand, we control for intra-country serial correlation.

\subsection{Results}

We start our analysis by estimating equation (1), using the set of control variables described above. The results are reported in the first column of Table 1A. As can be seen, the coefficient on excessive wage is negative and statistically significant. As the theory predicts, an increase in excessive wage tends to increase the cost of production in business sector putting a downward pressure in the profit share. The reer variable is negative and statistical significant, showing that deterioration in competitiveness of the

\footnotetext{
${ }^{14}$ Roodman (2006) suggests that the number of instruments should be less than or equal to the number of cross sections. Since system GMM uses more instruments than the difference GMM, it is not appropriate to use system GMM for a panel of 19 countries.
} 
home country is associated with a fall in the profit share. The coefficient on consumption, on the other hand, is positive and statistically significant, indicating that, as expected, a rise in demand has a positive impact on profits. Finally, unemployment is positively related with profits. This result may suggest that when unemployment is low firms face higher hiring and training cost since quits are procyclical. According to Akerlof et al. (1988) the opportunities for job switching are significantly greater when unemployment is low than when it is high.

In the second column of Table 1A, we model profits as a function of fiscal variables along with the control variables. As already mentioned, we have to omit one element of the budget constraint in order to avoid perfect multi-collinearity. We initially choose to omit budget surplus (deficit). Our results indicate a neutral effect of total expenditures on the profit share. On the other hand, an increase in taxation is negatively and significantly related to the profit share. In comparison with Alesina et al. (2002) results, we observe that although the coefficient of revenue turns out statistically significant and has the same effect on the profit share, expenditures don't seem to deteriorate profits.

Next, in column 3 of Table 1A, we omit expenditures, which seem to be a neutral financing element, while we include variable budget surplus in order to test our implicit assumption that the coefficient on budget surplus is insignificant. Results for variable revenues remain unaffected, while in line with our initial assumption, the coefficient of variable budget surplus is statistically insignificant. In the fourth column of Table 1A, we exclude from our regression variables expenditures and budget surplus, while revenues still have the same effect on profits. Finally, in the last column of Table 1A, we attempt to mis-specify the budget constraint in order to examine the importance of omitting from our regressions only elements with a neutral effect on profits. As can be seen, the coefficients on variables expenditures and budget surplus, when financed by increased taxation, are negatively biased and statistically significant. This result clearly indicates the importance of omitting only implicit financing elements from our specification.

Table 1A here 
However, these aggregate results are not very informative, since, as stated in the introduction, theory predicts that different expenditure and revenue items may have a different effect on profits. The impact of fiscal policy on the marginal product of capital depends on various factors such as the assumption made regarding the production function, the precise form of fiscal expansion, the way that the expansion is financed and the characteristics of the labour market [see among others Baxter and King (1993), Finn (1998), Fatas and Mihov (2001) and Ardagna (2007)]. Thus, the insignificant coefficient on expenditure does not rule out the possibility that some expenditure component have a significant relation with profits.

As a second step in our analysis, we breakdown public spending into capital expenditures and current expenditures, while tax revenues are sub-divided into direct taxation, indirect taxation and other revenues. As can be seen from the results in the first column of Table 1B, the coefficient on capital expenditures is positive and statistically significant. This result is consistent with several models that show that fiscal expansion in the form of a rise in public investment will increase the marginal product of capital either directly by shifting the private marginal product schedules or indirectly by correcting market failures that led to the underinvestment of the private sector in the market for infrastructure. [see among others Murphy at al. (1989), Baxter and King (1993) and Fatas and Mihov (2001)].

In Baxter and King (1993) capital expenditures are considered an input in the production function of the private sector with a direct impact on the marginal product of labour. Furthermore, investment in infrastructure, which is a large share of public investment, corrects the existence of market failures with positive externalities for the productivity of the public sector. As emphasized by Murphy at al. (1989) “...infrastructure can be a particularly appealing area for state intervention. First, coordination issues are especially important since the infrastructure serves many sectors simultaneously. Second, the projects tend to be large and time-consuming, so that capital market constraints and substantial uncertainty can deter private participation. Third, projects are fairly standard, and hence 'local knowledge' (Hayek 1945), which is perhaps the main advantage of private entrepreneurs over government, is not as essential as in other activities. 
Table 1B here

Turning to current expenditures, that in most of the cases consists almost the $90 \%$ of total expenditures, results reveal that it has no statistically significant effect on profits. This may explain our previous result of a statistically insignificant coefficient on aggregate expenditures. Later on, we disaggregate current expenditures in order to investigate if their neutrality reflects the different effect of various components of current expenditures on profits.

Regarding tax variables, direct taxation is negatively and significantly related to profits. An increase in direct taxation, that raises the cost of work relative to leisure (intratemporal effect) and induces individuals to work more when taxes are low (intertemporal effect), will reduce labor supply and the marginal product of labour in a perfectly competitive labour market. Moreover, in an imperfectly competitive labour market, the pre-tax real wage may rise with a negative impact on profits [see Alesina et al. (2002)]. We also find that indirect taxation has a negative and significant impact on profits. This result is more consistent with the presence of imperfect competition in the product market. Anderson et al. (2001) show that firms' "markup" will depend negatively on the level of an ad valorem indirect tax implying that indirect taxation will have a negative impact on profits. Finally, the coefficient on other revenues is negative but statistically insignificant.

Moving one step forward, in the second and third column of Table 1B, we drop current expenditures and other revenues, which are both found to be insignificantly related with the profit share, while we introduce budget surplus. As can be seen, results for capital expenditures, direct taxation and indirect taxation do not change, while, on the other hand, budget surplus is insignificantly related with the profit share. Finally, in the regressions reported in the last three columns of Table $1 \mathrm{~B}$ we omit the fiscal elements that appear insignificantly related to profits in our previous results. We do not omit from our estimated equation more than two neutral elements of the budget constraint -although this would have no impact on the results- because it would make harder to identify the assumed implicit financing element. As can be seen, once again, results for capital expenditures, direct taxation and indirect taxation remain unaffected. 


\section{Robustness Checks}

In this section we test the robustness of our results to five changes in the model specification. First, we check if our findings are driven by outlier observations. Second, we use a different indicator to measure profits. Third, we use an alternative set of control variables. Fourth, we proceed into a further disaggregation of the budgetary data. Finally, we investigate the impact of specific functional components of public spending on profits. ${ }^{15}$

\subsection{Testing for outliers}

In order to check that our findings are not driven by the presence of outliers, we first reestimate equation (1) by excluding all observations with estimated error in the upper or lower end 5.0-percentile range. This procedure reduces our sample, but it has the advantage of eliminating outlier observations. As expected, the adjusted $\mathrm{R}^{2}$ of the model is improved by the exclusion of these outlier observations. Results in Table 2 reveal that neither the sign nor the statistical significance of any of the variables has changed though. ${ }^{16}$ Alternatively, using Hadi (1992) method we check the fiscal data for outlier observations. Results reveal two outlier observations for variable other revenues (Norway 1990-94, 1995-00), but without any implication for our results.

Table 2 here

\subsection{Alternative dependent variable}

In all preceding analysis we have adopted the gross operating surplus as the indicator to measure profits. At this point, we want to check if our results are sensitive to this definition. For this reason, in this subsection we re-run equation (1) using net operating surplus as the dependent variable. Net (of depreciation) operating surplus (\% GDP) is defined as gross operating surplus minus consumption of fixed capital, and denoted as net

\footnotetext{
${ }^{15}$ Due to space considerations, in Table 1B we report the results only for the disaggregated fiscal variables. Note, however, that we also checked for robustness using the aggregated fiscal variables, but our basic findings do not seem to be affected.

${ }^{16}$ Due to space considerations, in Table 2 we do not report our estimates after dropping other revenues together with current expenditures and budget surplus from our model.
} 
profits. As can be seen in Table 3, results remain unaffected for all explanatory variables. It is also worth mentioning that, although, gross operating surplus is obtained by Annual Macroeconomic database of the European Commission, our results remain unaffected when we alternatively use the same indicator from OECD Economic Outlook database.

Table 3 here

\subsection{Alternative control variables}

Next we want to replace control variables that are related with potential bias: Firstly, the use of a generated regressor such as excessive wage implies that measurement errors, e.g., for productivity, will be classified as excessive wage increases. For example, even a purely competitive economy with no excessive wage increases will give non-zero values for the variable excessive wage. For this reason, instead of using excessive wage variable, we include in our model specification the two variables that we used for its construction. More specifically, we use labor productivity and the real compensation rate, obtained by OECD Economic outlook database and denoted as productivity and compensation, respectively.

Secondly, although we have found that the correlation between the growth rate of consumption and our fiscal variables is low, it is difficult to argue that fiscal policy will not affect the growth rate of consumption. For this reason, we alter the specification by using the initial growth rate of consumption, obtained by World Bank Development Indicators and denoted as iconsumption. We use this measure for two reasons, firstly because is highly correlated with the growth rate of consumption, secondly because is by even less correlated with the tax-spending variables. Note that our results regarding the impact of fiscal policy on profits would not change if we use iconsumption in all our previous estimations. ${ }^{17}$ As can be seen in Table 4, as expected, the coefficient of productivity is positive and statistically significant while variable compensation is negatively and significantly related with the profit share. Finally, the coefficient of

\footnotetext{
${ }^{17}$ We re-estimated regressions in table 4 by replacing excessive wage and consumption one at the time, while leaving all other control variables as introduced in table 1A, without any qualitative difference for our results.
} 
iconsumption is positive but statistically insignificant. As far as the fiscal variables are concerned, they retain their sign and statistical significance, indicating that our results are not sensitive to these changes in model specification.

Table 4 here

\subsection{Full disaggregation of budgetary data}

The next change we make to our estimated equation is to disaggregate even further the fiscal variables presented in Table 1B. First, we examine if different components of current expenditures have any particular effect on profits. For this reason we deviate from our previous specification by employing the basic sub-division of current expenditures into goods and services, interest payments and other current expenditures. ${ }^{18}$ As before, we omit from our estimated equation budget surplus, which is considered to be the implicit financing element. As can be seen, in the first column of Table 5, in line with our previous finding for current expenditures, we observe that all components of current expenditures are statistically insignificant, while all other fiscal variables retain their effect on profits. In line with our previous findings, both direct taxation and indirect taxation are still estimated to have a negative impact on profits, while the coefficient of other revenues is statistically insignificant.

As a next step we disaggregate public spending. In the second column of Table 5 variable goods and services is decomposed into wage expenditures and other goods and services. The former includes wages and salaries, while the latter includes all non-wage expenditures. The coefficient on wage expenditures is negative and significantly related with profits at the $10 \%$ level. In Alesina et al. (2002), the negative effect of public consumption on profits is mainly attributed to a 'labour market channel'. For instance, a rise in the public sector's wages and/or public employment will raise private sector's wages and reduce profits. On the contrary, we observe that other goods and services are significantly related with profits at the $10 \%$ level probably due to a direct positive demand impact of this category of government spending (e.g. spending on computers) on

\footnotetext{
18 Other current expenditures are current expenditures other than interest payments and goods and services expenditures.
} 
private production. In the last column of Table 5, we include variable non-wage expenditures that consists of capital expenditures and other goods and services, together with wage expenditures, interest payments as well as other current expenditures. As can be seen, in contrast with Alesina et al. (2002), the coefficient on non-wage expenditures is positive and significantly related with profits. This result is mainly attributed to the positive and highly significant coefficient of capital expenditures. On the other hand, once again, wage expenditures are negatively and significantly related with profits. Regarding other current expenditures, a large part of which is transfers, we observe an insignificant relation with profits. It is worth noting, that when Alesina et al. (2002) include year effects in their estimated model the coefficient on transfer expenditures turns out to be insignificantly related with profits.

Thus, the main reason for obtaining a statistically insignificant coefficient on current expenditures in Table 1B is that a 'labour channel' co-exists with other channels emphasized by the literature that relate fiscal policy to either a rise in monopolistic profits or to a rise in the marginal product of capital [see among others Dixon (1987), Mankiw (1988), Startz (1989), Coto-Martinez and Dixon (2003), Baxter and King (1993)].

Regarding the revenue side, direct taxation is broken-down into income taxation (taxation on income and profits) and other direct taxation. In many cases, variable other direct taxation consists entirely of social security contributions. The coefficient of income taxation in the second column of Table 5 is negative and statistically significant. This is an expected result since income taxation will distort labour and capital decisions with a negative impact on the profit share. What is surprising is that other direct taxation, although it represents a different form of direct taxation, is insignificantly related to profits. This result can be explained by the fact that this variable consists mainly by payments for social security contributions that may not be considered by individuals as taxation, but rather as a form of compulsory saving.

Table 5 here 


\subsection{Functional vs. Economic classification of expenditures}

So far we have used the economic classification of expenditures. At this point we want to investigate if any important functional component of capital expenditures (like healthcare and transport and communication expenditures) and/or current expenditures (like social security payments) have an impact on profits. So, our primary objective is to investigate the impact of all functional elements that compose "productive" and 'unproductive' expenditures as defined by KBG.

To that purpose, initially we construct variables productive expenditures and unproductive expenditures, based on KBG methodology. Among productive expenditures, KBG include those devoted to general public services ( $g p s$ ), defense (defense), health (health), education (education), housing (housing) and transport and communication (transport). Additionally, productive expenditures include other expenditures, although results remain unaffected if we introduce this fiscal element as a separate variable in econometric specification. On the other hand, unproductive expenditures include social security and welfare (social), recreation (recreation) and expenditures on economic services (economic). The definition of productive expenditures and unproductive expenditures differs across columns in Table 6. In particular, in the first column we use the basic specification described above. In columns 2 to 7 each time we exclude from productive expenditures one fiscal element in order to introduce it as a separate variable in econometric specification. For instance, in the second column we extract general public services expenditures $(g p s)$ from productive expenditures and we include it as a separate variable in specification. We follow the same procedure in columns 8 to 10 for unproductive expenditures. More specifically, in column 8 we extract social security and welfare expenditures (social) from unproductive expenditures and we include it as a separate variable in specification. This procedure allows us, on the one hand, to have a fully specified budget constraint, and on the other hand to investigate the relation of every functional component of public spending with profits.

Turning to the results, the coefficients on productive expenditures and unproductive expenditures are insignificantly related with profits. At the same time all tax variables retain their effects on profits. More specifically, direct taxation and indirect 
taxation variables seem to deteriorate profits, while other revenues variable has an insignificant relation with profits. Concerning the functional components of public spending, we find that the coefficient on transport variable is positive and significantly related with profits. This result is consistent with our pervious finding for a positive effect of capital expenditures on profits since both transport and communication expenditures are considered 'productive' expenditure that have a positive impact on the marginal product of capital and consequently of the profit share. On the contrary, we observe that the coefficient on variable defense is negatively and significantly related to profits indicating that a fall in defense expenditures would raise aggregate profits. In the literature, there is much controversy over whether defense expenditure should be considered as a 'productive' expenditure or not. On the one hand, such spending promotes growth through technological innovations that spill over civil industries and/or increased capital stock utilization [see among others Mueller and Atesoglu (1993), Kollias et al. (2007)]. On the other hand, defense expenditures has been found to have growth/investment retarding effects mainly through misallocation of resources away from growing sectors, investment crowding-out and inflationary pressures [see among others Smith (1980), Mintz and Huang (1990), Galvin (2003)].

Table 6 here

\section{Conclusions}

This paper aims at analyzing the impact of fiscal policy on profits. For that purpose, we estimate a profit equation that takes into account the fiscal policy of the government. In every step of our analysis, we respect the government's budget constraint, while we disaggregate it in a way that allows us to distinguish between productive and unproductive spending on the one hand, and direct (distortionary) and indirect (nondistortionary) taxation on the other hand.

We conduct our empirical analysis for 19 OECD countries during the period 1975-1999. Regarding the non-fiscal variables, we find that profits depend negatively on the part of wages that is not explained by productivity and positively on the growth rate of consumption. As far as fiscal variables are concerned, we observe that a rise in 
'productive' capital expenditures will tend to increase profits. On the contrary, current expenditures seem to have no impact on profits. However, a more detailed sub-division of current expenditures reveals that wages and salaries expenditures deteriorate profits, while non-wage expenditures have a positive impact on profits. Concerning the functional components of public spending, we have indications that transport and communication expenditures increase profits, while the opposite holds for defense expenditures. On the revenue side, both direct and indirect taxation tend to decrease profits while a further disaggregation of direct taxation reveals that certain items such as social security contributions have no impact on profits. 


\section{REFERENCES}

Abel, A., Blanchard, O., (1986): The present value of profits and cyclical movements in investment, Econometrica, 54:2, 249--73.

Adam, C., Bevan, D., (2005): Fiscal deficits and growth in developing countries, Journal of Public Economics, 89:4, 571--97.

Akerlof, G, Rose, A., Yellen, J., (1988): Job Switching and Job Satisfaction in the U.S. Labor Market, Brookings Papers on Economic Activity, 1988:2, 495--594.

Alesina, A., Ardagna, S., Perotti, R., Schiantarelli, F., (1999): Fiscal policy, profits and investment, NBER Working paper No.7207.

Alesina, A., Ardagna, S., Perotti, R., Schiantarelli, F., (2002): Fiscal policy, profits and investment, The American Economic Review, 92:3, 571--589.

Anderson, S., De-Palma A., Kreider B., (2000): The efficiency of indirect taxes under imperfect competition, Journal of Public Economics 81:2, 231--251.

Angelopoulos, K., Economides, G., Kammas, P., (2007): Tax-spending policies and economic growth: Theoretical predictions and evidence from the OECD, European Journal of Political Economy, 23:4, 885--902.

Annual Macroeconomic database of the European Commission, European Commission, Economic and Financial Affairs Indicators,

$\mathrm{http} / / /$ ec.europa.eu/economy_finance/db_indicators/db_indicators8646_en.htm

Arellano, M., Bond. S., (1991): Some tests of specification for panel data: Monte Carlo evidence and an application to employment equations, Review of Economic Studies 58:2, 277--97.

Ardagna, S., (2007): Fiscal policy in unionized labor markets, Journal of Economic Dynamics and Control, 31:5, 1498--1534.

Aschauer, D., (1989): Is public expenditure productive? , Journal of Monetary Economics $23: 2,177--200$.

Baker D., Bradford Delong J., Krugman P., (2005): Asset returns and economic growth, Brookings Papers on Economic Activity, 36:1, 289--315.

Baltagi, B., (2005): Econometric analysis of panel data. $3^{\text {rd }}$ ed. Chichester England: John Wiley \& Sons.

Barro, R., (1990): Government spending in a simple model of endogenous growth, Journal of Political Economy, 98:5, 103--26. 
Baxter, M., King, R., (1993): Fiscal policy in general equilibrium, American Economic Review, 83:3, 315--334.

Beck, N., Katz, J., (1995): What to do (and not to do) with Time-Series Cross Section Data, The American Political Science Review, 89:3, 634--647.

Beetsma, R., (2008): A survey of the effects of discretionary fiscal policy, Studier i Finanspolitik No.2008/2.

Blanchard, O., Perotti, R., (2002): An empirical characterization of the dynamic effects of changes in government spending and taxes on output, The Quarterly Journal of Economics, 117:4, 1329--1368.

Bleaney, M., Gemmell, N., Kneller, R., (2001): Testing the endogenous growth model: public expenditure, taxation, and growth over the long run, Canadian Journal of Economics, 34:1, 36--57.

Bose, N., Haque, E., Osborn, D., (2007): Public expenditure and economic growth: a disaggregated analysis for developing countries, The Manchester School, 75:5, 533--56.

Burnside, C., Eichenbaum, M., Fisher J., (2003): Fiscal shocks and their consequence, NBER Working Paper No.9772.

Chirinko, R., (1993): Business fixed investment spending: modelling strategies, empirical results and policy implications, Journal of Economic Literature, 31:4, 1875--1911.

Coto-Martinez, J., Dixon, H., (2003): Profits, mark-ups and entry: fiscal policy in an open economy, Journal of Economic Dynamics and Control 274:4, 573--597.

Devarajan, S., Swaroop, V., Heng-fu Zou, (1996): The composition of public expenditure and economic growth, Journal of Monetary Economics, 37:2, 313--344.

Dixon, H., (1987): A simple model of imperfect competition with Walrasian features, Oxford Economic Papers, 39:1, 134--160.

Drukker, D., (2003): "XTSERIAL", testing for Serial Correlation in Linear Panel-data Models, Stata Journal 3, 168--177.

ECB Monthly Bulletin (2004): Measuring and analyzing profit developments in the Euro area, January.

Fatas, A., Mihov, I., (2001): The effects of fiscal policy on consumption and employment: theory and evidence, CEPR Discussion Paper No. 2760.

Finkel, S., Tuttle D., (1971): Determinants of the aggregate profits margin source, Journal of Finance, 26: 5, 1067--1075. 
Finn, G., (1998): Cyclical effects of government's employment and goods purchases, International Economic Review, 39:3, 635--637.

Galvin, H., (2003): The impact of defense spending on the economic growth of developing countries: A cross-section study, Defense and Peace Economics, 14:1, 51--59.

Garcia-Penalosa, C., Turnovsky, S., (2007): Growth, income inequality, and fiscal policy: What are the relevant trade-offs? , Journal of Money, Credit and Banking, 39:2-3, 369-394.

Global Development Network Growth Database, http://dri.fas.nyu.edu/object/dri.resources.growthdatabase

Gosh, S., Georgiou, A., (2008): The composition of government spending and growth: is current or capital spending better?, Oxford Economic Papers, 60:3, 484--516.

Greene, W., (2000): Econometric Analysis. $3^{\text {rd }}$ ed., Upper Saddle River, NJ: PrenticeHall.

Hadi, A., (1992): Identifying multiple outliers in multivariate data, Journal of the Royal Statistical Society, Series B, 54:3, 761--771.

Hasett, K., Hubbard R., (1996): Tax policy and investment, NBER Working paper No. 5683.

Hayek, F., (1945): The Use of Knowledge in Society, American Economic Review, 35: 4, 519--530.

Hemming, R., Kell M., Mahfouz S., (2000): The effectiveness of fiscal policy in stimulating economic activity - A review of the literature", IMF Working paper No. $02 / 208$

International Monetary Found, International Financial Statistics database, http://www.imfstatistics.org/imf/

Kneller, R., Bleaney, M., Gemmell, N., (1999): Fiscal policy and growth: evidence from OECD countries, Journal of Public Economics, 74:2, 171--190.

Kollias, C., Mylonidis, S., Paleologou, S. M., (2007): A Panel Data Analysis of the Nexus Between Defense Spending and Growth in the European Union: A Reply', Defense and Peace Economics, 18:1, 75--85.

Malley, J., Moutos, T., (2006): Do excessive wage increases raise imports? Theory and evidence, Japan and the World Economy, 82:2, 194--220. 
Mankiw, N.G., (1988): Imperfect competition and the Keynesian cross, Economic Letters 26:1, 7--13.

McGahan, A., Porter M., (1999): The persistence of shocks to profitability, Review of Economics and Statistics, 81:1, 143--53.

Mendoza, E., Milesi-Ferretti, G., Asea, P., (1997): On the effectiveness of tax policy in altering long-run growth: Harberger's superneutrality conjecture, Journal of Public Economics, 66:1, 99--126.

Mintz, A., Huang, C., (1990): Defense expenditures, economic growth and the 'peace dividend', American Political Science Review, 84:4, 1283--1293.

Mueller, M., Atesoglu, S., (1993): Defense spending, technological change and economic growth in the United States, Defence Economics, 4:2, 259--269.

Murphy, K., Shleifer, A., Vishny, R., (1989): Industrialization and the big push, Journal of Political Economy 97, 1003--26.

Nunziata, L., (2000): "HETGROT", A Stata command for a likelihood ratio test for groupwise Heteroskedasticity. http://www.decon.unipd.it/ nunziata/software.htm

Pagan, A., (1984): Econometric issues in the analysis of regressions with generated regressors, International Economic Review, 25:1, 221--247.

Perotti, R., (2005): Estimating the effects of fiscal policy in OECD countries, CEPR Discussion paper No.4842.

Perotti, R., Kontopoulos Y., (2002): Fragmented fiscal policy, Journal of Public Economics, 86:2, 191--222.

Phelps E., (1994): Structural slumps: the modern equilibrium theory of unemployment, interest and assets, Harvard University Press.

Pudney, E., (1982): The identification of rational expectations models under structural neutrality, Journal of Economic Dynamics and Control, 61:4, 117--121.

Ravn, M., Schmitt-Grohe, S., Uribe M., (2006): Pricing to habits and the law of one price, NBER Working Papers No. 12731.

Roodman, D., (2006): How to do xtabond2: An introduction to "Difference" and "System" GMM in Stata, Center for Global Development, Working Paper No. 103.

Schmalensee, R., (1989): Intra-industry profitability differences in US manufacturing: 1953-1983, Journal of Industrial Economics, 37:4, 337--357. 
SourceOECD, OECD Economic Outlook database, http://masetto.sourceoecd.org/vl=7882792/cl=16/nw=1/rpsv/home.htm

Smith, R., (1980): Military expenditure and investment in OECD countries 1954-73, Journal of Comparative Economics, 4:1, 19--32.

Startz, R., (1989): Monopolistic competition as a foundation for Keynesian macroeconomic models, Quarterly Journal of Economics 104:4, 737--752.

Woodridge, J. M, (2002): Econometric Analysis of Cross Section and Panel Data, MIT Press, Cambridge, MA.

World Bank, World Bank Developments Indicators, http://ddpext.worldbank.org/ext/DDPQQ/member.do? method=getMembers\&userid=1\&q ueryId $=6$ 
Appendix. Data sources and descriptive statistics

\begin{tabular}{|c|c|c|c|c|c|c|c|}
\hline Variable & Description & Obs. & Mean & Std. dev. & Min & $\operatorname{Max}$ & Source \\
\hline profits & $\begin{array}{l}\text { Gross operating } \\
\text { surplus as a share } \\
\text { of GDP }(\%)\end{array}$ & 92 & 37.219 & 4.401 & 27.539 & 47.860 & $\begin{array}{l}\text { Annual } \\
\text { Macroeconomic } \\
\text { database of the } \\
\text { European Commission } \\
(A M E C O)\end{array}$ \\
\hline net profits & $\begin{array}{l}\text { Net operating } \\
\text { surplus as a share } \\
\text { of GDP }(\%)\end{array}$ & 92 & 23.345 & 4.536 & 15.115 & 36.492 & $A M E C O$ \\
\hline expenditures & $\begin{array}{l}\text { Total expenditures } \\
\text { as a share of GDP } \\
(\%)\end{array}$ & 93 & 35.915 & 9.897 & 15.888 & 56.700 & $\begin{array}{l}\text { Global Development } \\
\text { Network Growth } \\
\text { Database }(G D N G D)\end{array}$ \\
\hline revenues & $\begin{array}{l}\text { Total revenues as } \\
\text { a share of GDP } \\
(\%)\end{array}$ & 93 & 32.323 & 9.119 & 9.891 & 51.207 & $G D N G D$ \\
\hline capital expenditures & $\begin{array}{l}\text { Capital } \\
\text { expenditures as a } \\
\text { share of GDP }(\%)\end{array}$ & 93 & 2.378 & 1.124 & 0.390 & 5.125 & $G D N G D$ \\
\hline current expenditures & $\begin{array}{l}\text { Current } \\
\text { expenditures as a } \\
\text { share of GDP }(\%)\end{array}$ & 93 & 33.435 & 9.501 & 12.638 & 51.987 & $G D N G D$ \\
\hline goods and services & $\begin{array}{l}\text { Goods and } \\
\text { services } \\
\text { expenditures as a } \\
\text { share of GDP (\%) }\end{array}$ & 93 & 8.184 & 2.710 & 2.180 & 16.491 & $G D N G D$ \\
\hline wage expenditures & $\begin{array}{l}\text { Wages and } \\
\text { salaries } \\
\text { expenditures as a } \\
\text { share of GDP }(\%)\end{array}$ & 87 & 3.952 & 1.725 & 1.610 & 8.330 & $G D N G D$ \\
\hline other goods and services & $\begin{array}{l}\text { Other purchase of } \\
\text { goods and services } \\
\text { as a share of GDP } \\
(\%)\end{array}$ & 87 & 8.145 & 2.385 & 0.395 & 12.478 & $G D N G D$ \\
\hline non-wage expenditures & $\begin{array}{l}\text { Sum of capital } \\
\text { expenditures and } \\
\text { other purchase of } \\
\text { goods and services } \\
\text { as a share of GDP } \\
(\%)\end{array}$ & 87 & 6.432 & 1.927 & 2.001 & 10.185 & $\begin{array}{l}\text { Own calculations, } \\
\text { data taken from } \\
G D N G D\end{array}$ \\
\hline other current expenditures & $\begin{array}{l}\text { Other current } \\
\text { expenditures, } \\
\text { other than goods } \\
\text { and services and } \\
\text { interest payments, } \\
\text { as a share of GDP } \\
\text { (\%) }\end{array}$ & 93 & 21.648 & 7.251 & 8.462 & 40.338 & $\begin{array}{l}\text { Own calculations, } \\
\text { data taken from } \\
G D N G D\end{array}$ \\
\hline interest payments & $\begin{array}{l}\text { Interest payments } \\
\text { expenditures as a } \\
\text { share of GDP }(\%)\end{array}$ & 93 & 3.599 & 2.372 & 0.372 & 10.779 & $G D N G D$ \\
\hline productive expenditures & $\begin{array}{l}\text { Sum of productive } \\
\text { expenditures and } \\
\text { other } \\
\text { expenditures, as a } \\
\text { share of GDP }(\%)\end{array}$ & 78 & 18.889 & 5.657 & 8.193 & 32.536 & $\begin{array}{l}\text { Own calculations } \\
\text { based on KBG } \\
\text { methodology, data } \\
\text { taken from GDNGD }\end{array}$ \\
\hline
\end{tabular}




\begin{tabular}{|c|c|c|c|c|c|c|c|}
\hline unproductive expenditures & $\begin{array}{l}\text { Unproductive } \\
\text { expenditures as a } \\
\text { share of GDP (\%) }\end{array}$ & 78 & 16.349 & 4.961 & 6.672 & 27.494 & $\begin{array}{l}\text { Own calculations } \\
\text { based on KBG } \\
\text { methodology, data } \\
\text { taken from } G D N G D\end{array}$ \\
\hline gps & $\begin{array}{l}\text { General public } \\
\text { services } \\
\text { expenditures, as } \\
\text { share of GDP }(\%)\end{array}$ & 81 & 2.112 & 0.818 & 0.545 & 3.803 & $G D N G D$ \\
\hline defense & $\begin{array}{l}\text { Defense } \\
\text { expenditures, as } \\
\text { share of GDP }(\%)\end{array}$ & 81 & 2.389 & 1.086 & 0.919 & 5.741 & $G D N G D$ \\
\hline education & $\begin{array}{l}\text { Education } \\
\text { expenditures, as } \\
\text { share of GDP (\%) }\end{array}$ & 81 & 2.850 & 1.939 & 0.187 & 7.452 & $G D N G D$ \\
\hline health & $\begin{array}{l}\text { Health } \\
\text { expenditures, as } \\
\text { share of GDP }(\%)\end{array}$ & 81 & 3.911 & 2.189 & 0.183 & 7.764 & $G D N G D$ \\
\hline housing & $\begin{array}{l}\text { Housing } \\
\text { expenditures, as } \\
\text { share of GDP (\%) }\end{array}$ & 81 & 0.813 & 0.625 & 0.104 & 2.898 & $G D N G D$ \\
\hline transport & $\begin{array}{l}\text { Transport and } \\
\text { communication } \\
\text { expenditures, as } \\
\text { share of GDP }(\%)\end{array}$ & 78 & 1.539 & 0.902 & 0.065 & 4.770 & $G D N G D$ \\
\hline social & $\begin{array}{l}\text { Social security and } \\
\text { welfare } \\
\text { expenditures, as } \\
\text { share of GDP }(\%)\end{array}$ & 81 & 13.568 & 4.478 & 5.968 & 23.301 & $G D N G D$ \\
\hline recreation & $\begin{array}{l}\text { Expenditures on } \\
\text { recreational, } \\
\text { cultural and } \\
\text { religion affairs }\end{array}$ & 81 & 0.278 & 0.174 & 0.020 & 0.747 & $G D N G D$ \\
\hline economic & $\begin{array}{l}\text { Expenditures on } \\
\text { economic affairs } \\
\text { and services }\end{array}$ & 78 & 2.341 & 1.350 & 0.523 & 6.997 & $G D N G D$ \\
\hline direct taxation & $\begin{array}{l}\text { Sum of } \\
\text { distortionary } \\
\text { taxation as a share } \\
\text { of GDP }(\%)\end{array}$ & 93 & 19.754 & 6.098 & 7.090 & 34.309 & $\begin{array}{l}\text { Own calculations } \\
\text { based on KBG } \\
\text { methodology, data } \\
\text { taken from } G D N G D\end{array}$ \\
\hline income taxation & $\begin{array}{l}\text { Taxation on } \\
\text { income and profit } \\
\text { as a share of GDP } \\
(\%)\end{array}$ & 94 & 9.824 & 3.829 & 2.882 & 16.907 & $G D N G D$ \\
\hline other direct taxation & $\begin{array}{l}\text { Distortionary } \\
\text { taxation, other } \\
\text { than income and } \\
\text { profits taxation, as } \\
\text { a share of GDP } \\
(\%)\end{array}$ & 93 & 9.858 & 5.893 & 0.073 & 20.753 & $\begin{array}{l}\text { Own calculations, } \\
\text { data taken from } \\
G D N G D\end{array}$ \\
\hline indirect taxation & $\begin{array}{l}\text { Sum of taxation on } \\
\text { domestic goods } \\
\text { and services and } \\
\text { international trade } \\
\text { taxation, as a share } \\
\text { of GDP }(\%)\end{array}$ & 94 & 9.437 & 4.171 & 0.950 & 16.608 & $\begin{array}{l}\text { Own calculations, } \\
\text { data taken from } \\
G D N G D\end{array}$ \\
\hline
\end{tabular}




\begin{tabular}{|c|c|c|c|c|c|c|c|}
\hline other revenues & $\begin{array}{l}\text { Other revenues as } \\
\text { a share of GDP } \\
(\%)\end{array}$ & 93 & 3.557 & 1.840 & 0.894 & 9.374 & $\begin{array}{l}\text { Own calculations } \\
\text { based on KBG } \\
\text { methodology, data } \\
\text { taken from } G D N G D\end{array}$ \\
\hline budget surplus & $\begin{array}{l}\text { Budget } \\
\text { surplus/deficit as a } \\
\text { share of GDP (\%) }\end{array}$ & 92 & -4.013 & 3.357 & -15.042 & 2.157 & $G D N G D$ \\
\hline excessive wage & $\begin{array}{l}\text { We regress the } \\
\text { natural logarithm } \\
\text { of real } \\
\text { compensation rate } \\
\text { on the natural } \\
\text { logarithm of an } \\
\text { index of } \\
\text { productivity }\end{array}$ & 85 & 1.060 & 2.451 & -5.799 & 5.743 & $\begin{array}{l}\text { Own calculations, } \\
\text { data taken } \\
\text { SourceOECD, OECD } \\
\text { Economic Outlook } \\
\text { database }\end{array}$ \\
\hline consumption & $\begin{array}{l}\text { Growth rate of } \\
\text { final consumption } \\
\text { expenditure }(\%)\end{array}$ & 92 & 2.476 & 1.222 & -0.899 & 5.687 & $\begin{array}{l}\text { World Bank } \\
\text { Development } \\
\text { Indicators }(W D I)\end{array}$ \\
\hline iconsumption & $\begin{array}{l}\text { Initial growth rate } \\
\text { of final } \\
\text { consumption } \\
\text { expenditure }(\%)\end{array}$ & 92 & 2.622 & 2.004 & -1.990 & 11.863 & $W D I$ \\
\hline reer & $\begin{array}{l}\text { Real effective } \\
\text { exchange rates } \\
\text { index }\end{array}$ & 86 & 104.134 & 12.858 & 58.822 & 141.718 & $\begin{array}{l}\text { International } \\
\text { Financial Statistics }\end{array}$ \\
\hline unemployment & $\begin{array}{l}\text { Unemployment } \\
\text { rate }(\%)\end{array}$ & 92 & 6.927 & 3.555 & 0.405 & 16.701 & $\begin{array}{l}\text { SourceOECD, OECD } \\
\text { Economic outlook. } \\
\text { database }\end{array}$ \\
\hline productivity & Labor productivity & 87 & 80.516 & 12.052 & 47.979 & 99.724 & $\begin{array}{l}\text { SourceOECD, } \\
\text { Economic Outlook } \\
\text { database }\end{array}$ \\
\hline compensation & $\begin{array}{l}\text { Real compensation } \\
\text { rate }\end{array}$ & 84 & 86.606 & 9.401 & 67.134 & 105.198 & $\begin{array}{l}\text { SourceOECD, } \\
\text { Economic Outlook } \\
\text { database }\end{array}$ \\
\hline
\end{tabular}


Table 1A

Benchmark findings

\begin{tabular}{|c|c|c|c|c|c|}
\hline Dependent variable: profits & $(1)$ & (2) & (3) & (4) & $(5)$ \\
\hline Method: & FE & FE & FE & FE & FE \\
\hline Omitted fiscal variable: & - & surplus & expend. & $\begin{array}{l}\text { expend., } \\
\text { surplus }\end{array}$ & revenues \\
\hline expenditures & - & $\begin{array}{l}-0.043 \\
(-0.38)\end{array}$ & - & - & $\begin{array}{l}-0.243^{*} \\
(-1.87)\end{array}$ \\
\hline revenues & - & $\begin{array}{l}-0.247 * * * \\
(-3.23)\end{array}$ & $\begin{array}{l}-0.293 * * \\
(-2.78)\end{array}$ & $\begin{array}{l}-0.277^{* *} \\
(-2.53)\end{array}$ & - \\
\hline budget surplus & - & - & $\begin{array}{l}0.076 \\
(0.83)\end{array}$ & - & $\begin{array}{l}-0.138^{*} \\
(-1.88)\end{array}$ \\
\hline excessive wage & $\begin{array}{l}-0.318^{* * *} \\
(-6.37)\end{array}$ & $\begin{array}{l}-0.322 * * * \\
(-7.39)\end{array}$ & $\begin{array}{l}-0.318^{* * *} \\
(-6.94)\end{array}$ & $\begin{array}{l}-0.327 * * * \\
(-6.88)\end{array}$ & $\begin{array}{l}-0.316^{* * * *} \\
(-7.26)\end{array}$ \\
\hline reer & $\begin{array}{l}-0.034^{* *} \\
(-2.11)\end{array}$ & $\begin{array}{l}-0.016 \\
(-0.79)\end{array}$ & $\begin{array}{l}-0.018 \\
(-0.91)\end{array}$ & $\begin{array}{l}-0.015 \\
(-0.68)\end{array}$ & $\begin{array}{l}-0.023 \\
(-1.23)\end{array}$ \\
\hline consumption & $\begin{array}{l}0.626 * * * \\
(3.38)\end{array}$ & $\begin{array}{l}0.442 * * \\
(2.83)\end{array}$ & $\begin{array}{l}0.403 * * \\
(2.43)\end{array}$ & $\begin{array}{l}0.468 * * * \\
(3.38)\end{array}$ & $\begin{array}{l}0.479 * * * \\
(2.88)\end{array}$ \\
\hline unemployment & $\begin{array}{l}0.177 * \\
(1.97) \\
\end{array}$ & $\begin{array}{l}0.265 * * \\
(2.22) \\
\end{array}$ & $\begin{array}{l}0.277 * * \\
(2.48) \\
\end{array}$ & $\begin{array}{l}0.241 * * * \\
(2.97)\end{array}$ & $\begin{array}{l}0.290 * * \\
(2.38) \\
\end{array}$ \\
\hline $\begin{array}{l}\text { Adjusted } \mathrm{R}^{2} \\
\text { Observations }\end{array}$ & $\begin{array}{l}0.643 \\
79 \\
\end{array}$ & $\begin{array}{l}0.720 \\
77 \\
\end{array}$ & $\begin{array}{l}0.726 \\
77 \\
\end{array}$ & $\begin{array}{l}0.723 \\
77 \\
\end{array}$ & $\begin{array}{l}0.693 \\
77 \\
\end{array}$ \\
\hline \multicolumn{6}{|l|}{ Specification tests } \\
\hline $\mathrm{N}_{1}$ & 0.000 & 0.000 & 0.000 & 0.000 & 0.000 \\
\hline $\mathrm{N}_{2}$ & 0.012 & 0.051 & 0.024 & 0.024 & 0.074 \\
\hline $\mathrm{N}_{3}$ & 0.022 & 0.003 & 0.001 & 0.002 & 0.006 \\
\hline $\mathrm{N}_{4}$ & 0.388 & 0.351 & 0.156 & 0.394 & 0.586 \\
\hline $\mathrm{N}_{5}$ & 0.000 & 0.000 & 0.000 & 0.000 & 0.000 \\
\hline $\mathrm{N}_{6}$ & 0.000 & 0.000 & 0.000 & 0.000 & 0.000 \\
\hline
\end{tabular}

Notes: t-statistics, calculated using robust and clustered standard errors, are reported in parentheses. $* * *$ denotes significance at $\mathrm{N}_{2}=$ Breusch and Pagan LM tes

$\begin{aligned} \mathrm{N}_{2} & =\text { Hausman tes } \\ \mathrm{N}_{3} & =\text { F- test time }\end{aligned}$

$\mathrm{N}_{4}=$ Davidson and MacKinnon test of exogeneity

$\mathrm{N}_{4}=$ Davidson and $\mathrm{N}_{5}=$ Likelihood ratio test for groupwise heteroskedasticity

$\mathrm{N}_{6}=\mathrm{LM}_{5}$ test for serial correlation

P-values are reported for the respective tests
Table 1B

Disaggregated Budgetary Data

\begin{tabular}{|c|c|c|c|c|c|c|}
\hline $\begin{array}{l}\text { Dependent variable: } \\
\text { profits }\end{array}$ & (1) & (2) & (3) & (4) & (5) & (6) \\
\hline Method: & FE & FE & FE & FE & FE & FE \\
\hline Omitted fiscal variable: & surplus & current exp. & other revenues & $\begin{array}{l}\text { current } \\
\text { exp., } \\
\text { surplus }\end{array}$ & $\begin{array}{l}\text { other rev., } \\
\text { surplus }\end{array}$ & $\begin{array}{l}\text { current exp., } \\
\text { other rev. }\end{array}$ \\
\hline capital expenditures & $\begin{array}{l}0.547 * * * \\
(3.07)\end{array}$ & $\begin{array}{l}0.603 * * * \\
(3.59)\end{array}$ & $\begin{array}{l}0.593^{* * * *} \\
(3.64)\end{array}$ & $\begin{array}{l}0.536^{* *} \\
(2.82)\end{array}$ & $\begin{array}{l}0.544^{* * * *} \\
(3.00)\end{array}$ & $\begin{array}{l}0.597^{* * *} \\
(3.40)\end{array}$ \\
\hline current expenditures & $\begin{array}{l}-0.055 \\
(-0.61)\end{array}$ & - & $\begin{array}{l}-0.011 \\
(-0.09)\end{array}$ & - & $\begin{array}{l}-0.081 \\
(-0.84)\end{array}$ & - \\
\hline direct taxation & $\begin{array}{l}-0.272^{* * * *} \\
(-3.98)\end{array}$ & $\begin{array}{l}-0.346^{* * * *} \\
(-3.37)\end{array}$ & $\begin{array}{l}-0.355^{* * * *} \\
(-3.12)\end{array}$ & $\begin{array}{l}-0.281 * * * \\
(-3.84)\end{array}$ & $\begin{array}{l}-0.276^{* * * *} \\
(-4.14)\end{array}$ & $\begin{array}{l}-0.364 * * * \\
(-3.26)\end{array}$ \\
\hline indirect taxation & $\begin{array}{l}-0.548^{* *} \\
(-2.49)\end{array}$ & $\begin{array}{l}-0.581 * * * \\
(-3.07)\end{array}$ & $\begin{array}{l}-0.559^{* *} \\
(-2.18)\end{array}$ & $\begin{array}{l}-0.625^{* *} \\
(-2.57)\end{array}$ & $\begin{array}{l}-0.506^{* *} \\
(-2.24)\end{array}$ & $\begin{array}{l}-0.569^{* *} \\
(-2.66)\end{array}$ \\
\hline other revenues & $\begin{array}{l}-0.115 \\
(-0.92)\end{array}$ & $\begin{array}{l}-0.137 \\
(-1.10)\end{array}$ & - & $\begin{array}{l}-0.156 \\
(-1.06)\end{array}$ & - & - \\
\hline budget surplus & - & $\begin{array}{l}0.084 \\
(1.02)\end{array}$ & $\begin{array}{l}0.084 \\
(0.76)\end{array}$ & - & - & $\begin{array}{l}0.093 \\
(1.03)\end{array}$ \\
\hline excessive wage & $\begin{array}{l}-0.391 * * * \\
(-7.67)\end{array}$ & $\begin{array}{l}-0.393^{* * * *} \\
(-8.17)\end{array}$ & $\begin{array}{l}-0.407^{* * *} \\
(-9.55)\end{array}$ & $\begin{array}{l}-0.393^{* * *} \\
(-7.28)\end{array}$ & $\begin{array}{l}-0.401 * * * \\
(-9.02)\end{array}$ & $\begin{array}{l}-0.408^{* * *} \\
(-9.83)\end{array}$ \\
\hline reer & $\begin{array}{l}-0.008 \\
(-0.44)\end{array}$ & $\begin{array}{l}-0.009 \\
(-0.53)\end{array}$ & $\begin{array}{l}-0.010 \\
(-0.59)\end{array}$ & $\begin{array}{l}-0.007 \\
(-0.35)\end{array}$ & $\begin{array}{l}-0.009 \\
(-0.52)\end{array}$ & $\begin{array}{l}-0.010 \\
(-0.60)\end{array}$ \\
\hline consumption & $\begin{array}{l}0.359 * * * \\
(3.90)\end{array}$ & $\begin{array}{l}0.327 * * * \\
(3.35)\end{array}$ & $\begin{array}{l}0.322 * * * * \\
(3.30)\end{array}$ & $\begin{array}{l}0.392^{* * * *} \\
(4.04)\end{array}$ & $\begin{array}{l}0.345^{* * * *} \\
(3.82)\end{array}$ & $\begin{array}{l}0.322^{* * * *} \\
(3.34)\end{array}$ \\
\hline unemployment & $\begin{array}{l}0.246 * \\
(1.80)\end{array}$ & $\begin{array}{l}0.245^{* *} \\
(2.08)\end{array}$ & $\begin{array}{l}0.232 * \\
(1.80)\end{array}$ & $\begin{array}{l}0.211^{\text {** }} \\
(2.46)\end{array}$ & $\begin{array}{l}0.248^{*} \\
(1.84)\end{array}$ & $\begin{array}{l}0.228^{*} \\
(2.01)\end{array}$ \\
\hline Adjusted $\mathrm{R}^{2}$ & 0.780 & 0.785 & 0.779 & 0.781 & 0.780 & 0.782 \\
\hline Observations & 77 & 77 & 77 & 77 & 77 & 77 \\
\hline \multicolumn{7}{|l|}{ Specification tests } \\
\hline $\mathrm{N}_{1}$ & 0.000 & 0.000 & 0.000 & 0.000 & 0.000 & 0.000 \\
\hline $\mathrm{N}_{2}$ & 0.104 & 0.076 & 0.042 & 0.046 & 0.046 & 0.031 \\
\hline $\mathrm{N}_{3}$ & 0.001 & 0.014 & 0.001 & 0.001 & 0.001 & 0.002 \\
\hline $\mathrm{N}_{4}$ & 0.612 & 0.539 & 0.519 & 0.808 & 0.409 & 0.389 \\
\hline $\mathrm{N}_{5}$ & 0.000 & 0.000 & 0.000 & 0.000 & 0.000 & 0.000 \\
\hline $\mathrm{N}_{6}$ & 0.001 & 0.001 & 0.001 & 0.001 & 0.001 & 0.001 \\
\hline
\end{tabular}

Notes: see Table 1A. 
Table 2

Disaggregated Budgetary Data, excluding outliers

\begin{tabular}{|c|c|c|c|}
\hline Dependent variable: profits & (1) & (2) & (3) \\
\hline Method: & FE & $\mathrm{FE}$ & FE \\
\hline Omitted fiscal variable: & surplus & current exp. & $\begin{array}{l}\text { current exp. } \\
\text { surplus }\end{array}$ \\
\hline capital expenditures & $\begin{array}{l}0.536^{*} \\
(1.72)\end{array}$ & $\begin{array}{l}0.603 * * \\
(2.07)\end{array}$ & $\begin{array}{l}0.548^{*} \\
(1.74)\end{array}$ \\
\hline current expenditures & $\begin{array}{l}-0.071 \\
(-0.69)\end{array}$ & - & - \\
\hline direct taxation & $\begin{array}{l}-0.268^{* * * *} \\
(-3.30)\end{array}$ & $\begin{array}{l}-0.341^{* * *} \\
(-3.50)\end{array}$ & $\begin{array}{l}-0.285^{* * *} \\
(-3.43)\end{array}$ \\
\hline indirect taxation & $\begin{array}{l}-0.597 * * \\
(-2.45)\end{array}$ & $\begin{array}{l}-0.624 * * \\
(-2.82)\end{array}$ & $\begin{array}{l}-0.696 * * \\
(-2.58)\end{array}$ \\
\hline other revenues & $\begin{array}{l}-0.083 \\
(-0.51)\end{array}$ & $\begin{array}{l}-0.111 \\
(-0.76)\end{array}$ & $\begin{array}{l}-0.145 \\
(-0.88)\end{array}$ \\
\hline budget surplus & - & $\begin{array}{l}0.096 \\
(0.93)\end{array}$ & - \\
\hline excessive wage & $\begin{array}{l}-0.398^{* * * *} \\
(-7.16)\end{array}$ & $\begin{array}{l}-0.406^{* * *} \\
(-7.55)\end{array}$ & $\begin{array}{l}-0.398^{* * *} \\
(-6.54)\end{array}$ \\
\hline reer & $\begin{array}{l}-0.011 \\
(-0.57)\end{array}$ & $\begin{array}{l}-0.012 \\
(-0.66)\end{array}$ & $\begin{array}{l}-0.008 \\
(-0.43)\end{array}$ \\
\hline consumption & $\begin{array}{l}0.361 * * * \\
(3.32)\end{array}$ & $\begin{array}{l}0.322 * * \\
(2.65)\end{array}$ & $\begin{array}{l}0.405^{* * *} \\
(3.90)\end{array}$ \\
\hline unemployment & $\begin{array}{l}0.275^{*} \\
(1.82)\end{array}$ & $\begin{array}{l}0.269 * * \\
(2.05)\end{array}$ & $\begin{array}{l}0.230^{* *} \\
(2.54)\end{array}$ \\
\hline $\begin{array}{l}\text { Adjusted } \mathrm{R}^{2} \\
\text { Observations }\end{array}$ & $\begin{array}{l}0.787 \\
71 \\
\end{array}$ & $\begin{array}{l}0.791 \\
71\end{array}$ & $\begin{array}{l}0.786 \\
71\end{array}$ \\
\hline \multicolumn{4}{|l|}{ Specification tests } \\
\hline $\mathrm{N}_{1}$ & 0.000 & 0.000 & 0.000 \\
\hline $\mathrm{N}_{2}$ & 0.351 & 0.564 & 0.410 \\
\hline $\mathrm{N}_{3}$ & 0.003 & 0.012 & 0.003 \\
\hline $\mathrm{N}_{4}$ & 0.639 & 0.548 & 0.861 \\
\hline $\mathrm{N}_{5}$ & 0.000 & 0.000 & 0.000 \\
\hline $\mathrm{N}_{6}$ & 0.001 & 0.001 & 0.001 \\
\hline
\end{tabular}

Notes: see Table 1A
Table 3

Disaggregated Budgetary Data, Alternative measure as Dependent variable

\begin{tabular}{|c|c|c|c|}
\hline Dependent variable: net profits & (1) & (2) & (3) \\
\hline Method: & FE & FE & FE \\
\hline Omitted fiscal variable: & surplus & current exp. & $\begin{array}{l}\text { current exp., } \\
\text { surplus }\end{array}$ \\
\hline capital expenditures & $\begin{array}{l}0.625^{*} \\
(1.89)\end{array}$ & $\begin{array}{l}0.668^{* *} \\
(2.08)\end{array}$ & $\begin{array}{l}0.627 * \\
(1.93)\end{array}$ \\
\hline current expenditures & $\begin{array}{l}0.009 \\
(0.10)\end{array}$ & - & - \\
\hline direct taxation & $\begin{array}{l}-0.295^{* *} \\
(-2.76)\end{array}$ & $\begin{array}{l}-0.333^{* *} \\
(-2.32)\end{array}$ & $\begin{array}{l}-0.294 * * \\
(-2.72)\end{array}$ \\
\hline indirect taxation & $\begin{array}{l}-0.474 * \\
(-1.89)\end{array}$ & $\begin{array}{l}-0.434^{*} \\
(-1.95)\end{array}$ & $\begin{array}{l}-0.461^{*} \\
(-1.80)\end{array}$ \\
\hline other revenues & $\begin{array}{l}-0.339^{*} \\
(-1.93)\end{array}$ & $\begin{array}{l}-0.320^{*} \\
(-1.90)\end{array}$ & $\begin{array}{l}-0.332^{*} \\
(-1.86)\end{array}$ \\
\hline budget surplus & - & $\begin{array}{l}0.051 \\
(0.51)\end{array}$ & - \\
\hline excessive wage & $\begin{array}{l}-0.327 * * * \\
(-4.93)\end{array}$ & $\begin{array}{l}-0.326^{* * *} \\
(-5.04)\end{array}$ & $\begin{array}{l}-0.327 * * * \\
(-4.96)\end{array}$ \\
\hline reer & $\begin{array}{l}-0.014 \\
(-0.68)\end{array}$ & $\begin{array}{l}-0.016 \\
(-0.78)\end{array}$ & $\begin{array}{l}-0.014 \\
(-0.70)\end{array}$ \\
\hline consumption & $\begin{array}{l}0.667 * * * \\
(6.03)\end{array}$ & $\begin{array}{l}0.622 * * * \\
(5.05)\end{array}$ & $\begin{array}{l}0.662 * * * \\
(5.36)\end{array}$ \\
\hline unemployment & $\begin{array}{l}0.265 \\
(1.56) \\
\end{array}$ & $\begin{array}{l}0.291 * \\
(1.87) \\
\end{array}$ & $\begin{array}{l}0.271 * * \\
(2.31) \\
\end{array}$ \\
\hline $\begin{array}{l}\text { Adjusted } \mathrm{R}^{2} \\
\text { Observations }\end{array}$ & $\begin{array}{l}0.644 \\
77\end{array}$ & $\begin{array}{l}0.646 \\
77\end{array}$ & $\begin{array}{l}0.649 \\
77\end{array}$ \\
\hline \multicolumn{4}{|l|}{ Specification tests } \\
\hline $\mathrm{N}_{1}$ & 0.000 & 0.000 & 0.000 \\
\hline $\mathrm{N}_{2}$ & 0.064 & 0.018 & 0.056 \\
\hline $\mathrm{N}_{3}$ & 0.113 & 0.143 & 0.100 \\
\hline $\mathrm{N}_{4}$ & 0.279 & 0.219 & 0.246 \\
\hline $\mathrm{N}_{5}$ & 0.000 & 0.000 & 0.000 \\
\hline $\mathrm{N}_{6}$ & 0.001 & 0.001 & 0.001 \\
\hline
\end{tabular}

Notes: see Table 1A. 
Table 4

Disaggregated Budgetary Data, Alternative control variables

\begin{tabular}{|c|c|c|c|}
\hline Dependent variable: net profits & $(1)$ & $(2)$ & $(3)$ \\
\hline Method: & $\mathrm{FE}$ & $\mathrm{FE}$ & FE \\
\hline Omitted fiscal variable: & surplus & current exp. & $\begin{array}{l}\text { current exp., } \\
\text { surplus }\end{array}$ \\
\hline capital expenditures & $\begin{array}{l}0.362^{*} \\
(1.89)\end{array}$ & $\begin{array}{l}0.391^{* *} \\
(2.05)\end{array}$ & $\begin{array}{l}0.354^{*} \\
(1.81)\end{array}$ \\
\hline current expenditures & $\begin{array}{l}-0.034 \\
(-0.36)\end{array}$ & - & - \\
\hline direct taxation & $\begin{array}{l}-0.282 * * * \\
(-2.88)\end{array}$ & $\begin{array}{l}-0.323 * * \\
(-2.73)\end{array}$ & $\begin{array}{l}-0.291 * * * \\
(-2.91)\end{array}$ \\
\hline indirect taxation & $\begin{array}{l}-0.500^{*} \\
(-2.00)\end{array}$ & $\begin{array}{l}-0.520 * * \\
(-2.45)\end{array}$ & $\begin{array}{l}-0.544 * * \\
(-2.41)\end{array}$ \\
\hline other revenues & $\begin{array}{l}-0.345^{* *} \\
(-2.36)\end{array}$ & $\begin{array}{l}-0.359 * * \\
(-2.68)\end{array}$ & $\begin{array}{l}-0.374 * * * \\
(-2.93)\end{array}$ \\
\hline budget surplus & - & $\begin{array}{l}0.048 \\
(0.62)\end{array}$ & - \\
\hline Productivity & $\begin{array}{l}0.396^{* * * *} \\
(6.74)\end{array}$ & $\begin{array}{l}0.391 * * * \\
(6.87)\end{array}$ & $\begin{array}{l}0.406^{* * *} \\
(7.27)\end{array}$ \\
\hline Compensation & $\begin{array}{l}-0.367 * * * \\
(-5.40)\end{array}$ & $\begin{array}{l}-0.362 * * * \\
(-5.31)\end{array}$ & $\begin{array}{l}-0.370^{* * *} \\
(-5.64)\end{array}$ \\
\hline Reer & $\begin{array}{l}-0.017 \\
(-0.80)\end{array}$ & $\begin{array}{l}-0.018 \\
(-0.84)\end{array}$ & $\begin{array}{l}-0.017 \\
(-0.79)\end{array}$ \\
\hline Iconsumption & $\begin{array}{l}0.088 \\
(1.33)\end{array}$ & $\begin{array}{l}0.088 \\
(1.25)\end{array}$ & $\begin{array}{l}0.093 \\
(1.34)\end{array}$ \\
\hline Unemployment & $\begin{array}{l}0.157 \\
(1.03) \\
\end{array}$ & $\begin{array}{l}0.159 \\
(1.18) \\
\end{array}$ & $\begin{array}{l}0.131 \\
(1.33)\end{array}$ \\
\hline $\begin{array}{l}\text { Adjusted } \mathrm{R}^{2} \\
\text { Observations }\end{array}$ & $\begin{array}{l}0.734 \\
77\end{array}$ & $\begin{array}{l}0.736 \\
77\end{array}$ & $\begin{array}{l}0.737 \\
77\end{array}$ \\
\hline \multicolumn{4}{|l|}{ Specification tests } \\
\hline $\begin{array}{c}\mathrm{N}_{1} \\
\mathrm{~N}_{2} \\
\mathrm{~N}_{3} \\
\mathrm{~N}_{4} \\
\mathrm{~N}_{5} \\
\mathrm{~N}_{6}\end{array}$ & $\begin{array}{l}0.000 \\
0.000 \\
0.089 \\
0.515 \\
0.004 \\
0.000\end{array}$ & $\begin{array}{l}0.000 \\
0.000 \\
0.185 \\
0.516 \\
0.015 \\
0.001\end{array}$ & $\begin{array}{l}0.000 \\
0.000 \\
0.112 \\
0.394 \\
0.013 \\
0.001 \\
\end{array}$ \\
\hline
\end{tabular}

Notes: see Table 1A 
Table 5

Disaggregated Budgetary Data, full disaggregation

\begin{tabular}{|c|c|c|c|}
\hline Dependent variable: profits & $(1)$ & $(2)$ & (3) \\
\hline Method: & $\mathrm{FE}$ & $\mathrm{FE}$ & $\mathrm{FE}$ \\
\hline Omitted fiscal variable: & surplus & surplus & surplus \\
\hline capital expenditures & $\begin{array}{l}0.588^{* * * *} \\
(3.43)\end{array}$ & $\begin{array}{l}0.676^{* * * *} \\
(3.95)\end{array}$ & - \\
\hline goods and services & $\begin{array}{l}-0.150 \\
(-0.69)\end{array}$ & - & - \\
\hline Wage expenditures & - & $\begin{array}{l}-0.583 * \\
(-1.88)\end{array}$ & $\begin{array}{l}-0.521^{*} \\
(-1.74)\end{array}$ \\
\hline Other goods and services & - & $\begin{array}{l}0.418^{*} \\
(1.72)\end{array}$ & - \\
\hline Non-wage expenditures & - & - & $\begin{array}{l}0.577 * * * \\
(3.94)\end{array}$ \\
\hline interest payments & $\begin{array}{l}-0.037 \\
(-0.24)\end{array}$ & $\begin{array}{l}0.062 \\
(0.46)\end{array}$ & $\begin{array}{l}0.053 \\
(0.37)\end{array}$ \\
\hline other current expenditures & $\begin{array}{l}-0.061 \\
(-0.60)\end{array}$ & $\begin{array}{l}-0.146 \\
(-1.20)\end{array}$ & $\begin{array}{l}-0.138 \\
(-1.09)\end{array}$ \\
\hline direct taxation & $\begin{array}{l}-0.287 * * * \\
(-4.01)\end{array}$ & - & $\begin{array}{l}-0.237 * * \\
(-2.57)\end{array}$ \\
\hline income taxation & - & $\begin{array}{l}-0.277 * * * \\
(-3.22)\end{array}$ & - \\
\hline other direct taxation & - & $\begin{array}{l}-0.195 \\
(-1.51)\end{array}$ & - \\
\hline indirect taxation & $\begin{array}{l}-0.551 * * \\
(-2.43)\end{array}$ & $\begin{array}{l}-0.632 * * * \\
(-2.95)\end{array}$ & $\begin{array}{l}-0.652 * * * \\
(-3.16)\end{array}$ \\
\hline other revenues & $\begin{array}{l}-0.094 \\
(-0.65)\end{array}$ & $\begin{array}{l}-0.140 \\
(-1.17)\end{array}$ & $\begin{array}{l}-0.166 \\
(-1.37)\end{array}$ \\
\hline budget surplus & - & - & - \\
\hline excessive wage & $\begin{array}{l}-0.388 * * * \\
(-7.69)\end{array}$ & $\begin{array}{l}-0.354 * * * \\
(-6.91)\end{array}$ & $\begin{array}{l}-0.357 * * * \\
(-7.19)\end{array}$ \\
\hline reer & $\begin{array}{l}-0.008 \\
(-0.45)\end{array}$ & $\begin{array}{l}-0.010 \\
(-0.48)\end{array}$ & $\begin{array}{l}-0.013 \\
(-0.57)\end{array}$ \\
\hline consumption & $\begin{array}{l}0.353 * * * \\
(3.69)\end{array}$ & $\begin{array}{l}0.258^{*} \\
(1.87)\end{array}$ & $\begin{array}{l}0.235^{*} \\
(1.96)\end{array}$ \\
\hline unemployment & $\begin{array}{l}0.259^{*} \\
(1.73) \\
\end{array}$ & $\begin{array}{l}0.245^{*} \\
(1.77) \\
\end{array}$ & $\begin{array}{l}0.226^{*} \\
(1.77) \\
\end{array}$ \\
\hline $\begin{array}{l}\text { Adjusted R }{ }^{2} \\
\text { Observations }\end{array}$ & $\begin{array}{l}0.774 \\
77 \\
\end{array}$ & $\begin{array}{l}0.794 \\
73 \\
\end{array}$ & $\begin{array}{l}0.798 \\
73 \\
\end{array}$ \\
\hline \multicolumn{4}{|l|}{ Specification tests } \\
\hline $\begin{array}{l}\mathrm{N}_{1} \\
\mathrm{~N}_{2} \\
\mathrm{~N}_{3} \\
\mathrm{~N}_{4} \\
\mathrm{~N}_{5} \\
\mathrm{~N}_{6} \\
\end{array}$ & $\begin{array}{l}0.000 \\
0.075 \\
0.003 \\
0.659 \\
0.000 \\
0.001 \\
\end{array}$ & $\begin{array}{l}0.000 \\
0.075 \\
0.097 \\
0.803 \\
0.000 \\
0.000 \\
\end{array}$ & $\begin{array}{l}0.000 \\
0.021 \\
0.032 \\
0.697 \\
0.000 \\
0.001 \\
\end{array}$ \\
\hline
\end{tabular}

Notes: see table 1A. 
Table 6

Functional vs. Economic classification of expenditures

\begin{tabular}{|c|c|c|c|c|c|c|c|c|c|c|}
\hline Dependent variable: profits & (1) & $(2)$ & (3) & (4) & (5) & (6) & (7) & (8) & (9) & $(10)$ \\
\hline Method: & $\mathrm{FE}$ & $\mathrm{FE}$ & $\mathrm{FE}$ & $\mathrm{FE}$ & $\mathrm{FE}$ & $\mathrm{FE}$ & $\mathrm{FE}$ & $\mathrm{FE}$ & FE & FE \\
\hline Omitted fiscal variable: & surplus & surplus & surplus & surplus & surplus & surplus & surplus & surplus & surplus & surplus \\
\hline expenditure category & - & gps & defense & education & health & housing & transport & social & recreation & economic \\
\hline productive expenditures & $\begin{array}{l}-0.059 \\
(-0.59)\end{array}$ & $\begin{array}{l}-0.070 \\
(-0.17)\end{array}$ & $\begin{array}{l}0.014 \\
(0.14)\end{array}$ & $\begin{array}{l}-0.081 \\
(-0.95)\end{array}$ & $\begin{array}{l}-0.128 \\
(-1.37)\end{array}$ & $\begin{array}{l}-0.066 \\
(-0.14)\end{array}$ & $\begin{array}{l}-0.106 \\
(-1.10)\end{array}$ & $\begin{array}{l}-0.081 \\
(-0.67)\end{array}$ & $\begin{array}{l}-0.060 \\
(-0.60)\end{array}$ & $\begin{array}{l}-0.079 \\
(-0.66)\end{array}$ \\
\hline unproductive expenditures & $\begin{array}{l}0.022 \\
(0.14)\end{array}$ & $\begin{array}{l}0.022 \\
(0.14)\end{array}$ & $\begin{array}{l}0.024 \\
(0.18)\end{array}$ & $\begin{array}{l}-0.072 \\
(-0.44)\end{array}$ & $\begin{array}{l}0.016 \\
(0.10)\end{array}$ & $\begin{array}{l}0.023 \\
(0.13)\end{array}$ & $\begin{array}{l}0.020 \\
(0.14)\end{array}$ & $\begin{array}{l}0.226 \\
(0.81)\end{array}$ & $\begin{array}{l}0.012 \\
(0.07)\end{array}$ & $\begin{array}{l}-0.040 \\
(-0.18)\end{array}$ \\
\hline expenditure category & - & $\begin{array}{l}-0.057 \\
(-0.52)\end{array}$ & $\begin{array}{l}-1.010^{* *} \\
(-2.12)\end{array}$ & $\begin{array}{l}0.619 \\
(1.37)\end{array}$ & $\begin{array}{l}0.232 \\
(1.24)\end{array}$ & $\begin{array}{l}-0.058 \\
(-0.57)\end{array}$ & $\begin{array}{l}0.883^{* *} \\
(2.44)\end{array}$ & $\begin{array}{l}-0.051 \\
(-0.22)\end{array}$ & $\begin{array}{l}0.550 \\
(0.30)\end{array}$ & $\begin{array}{l}0.216 \\
(0.72)\end{array}$ \\
\hline direct taxation & $\begin{array}{l}-0.275^{* *} \\
(-2.22)\end{array}$ & $\begin{array}{l}-0.276^{*} \\
(-1.85)\end{array}$ & $\begin{array}{l}-0.319^{* *} \\
(-2.83)\end{array}$ & $\begin{array}{l}-0.292 * * \\
(-2.58)\end{array}$ & $\begin{array}{l}-0.244 * * \\
(-2.10)\end{array}$ & $\begin{array}{l}-0.275^{* *} \\
(-2.13)\end{array}$ & $\begin{array}{l}-0.261 * * \\
(-2.54)\end{array}$ & $\begin{array}{l}-0.294 * * \\
(-2.56)\end{array}$ & $\begin{array}{l}-0.280 * * \\
(-2.35)\end{array}$ & $\begin{array}{l}-0.290 * * \\
(-2.48)\end{array}$ \\
\hline indirect taxation & $\begin{array}{l}-0.637 * * \\
(-2.19)\end{array}$ & $\begin{array}{l}-0.638^{* *} \\
(-2.15)\end{array}$ & $\begin{array}{l}-0.811 * * * \\
(-3.47)\end{array}$ & $\begin{array}{l}-0.707 * * \\
(-2.80)\end{array}$ & $\begin{array}{l}-0.687 * * \\
(-2.48)\end{array}$ & $\begin{array}{l}-0.636^{* *} \\
(-2.06)\end{array}$ & $\begin{array}{l}-0.706^{* *} \\
(-2.68)\end{array}$ & $\begin{array}{l}-0.634 * * \\
(-2.18)\end{array}$ & $\begin{array}{l}-0.617 * * \\
(-2.04)\end{array}$ & $\begin{array}{l}-0.643 * * \\
(-2.24)\end{array}$ \\
\hline other revenues & $\begin{array}{l}-0.107 \\
(-0.57)\end{array}$ & $\begin{array}{l}-0.108 \\
(-0.55)\end{array}$ & $\begin{array}{l}-0.109 \\
(-0.74)\end{array}$ & $\begin{array}{l}-0.079 \\
(-0.40)\end{array}$ & $\begin{array}{l}-0.004 \\
(-0.02)\end{array}$ & $\begin{array}{l}-0.108 \\
(-0.51)\end{array}$ & $\begin{array}{l}-0.007 \\
(-0.03)\end{array}$ & $\begin{array}{l}-0.117 \\
(-0.63)\end{array}$ & $\begin{array}{l}-0.111 \\
(-0.57)\end{array}$ & $\begin{array}{l}-0.114 \\
(-0.61)\end{array}$ \\
\hline budget surplus & - & - & - & - & - & - & - & - & - & - \\
\hline excessive wage & $\begin{array}{l}-0.384^{* * * *} \\
(-6.35)\end{array}$ & $\begin{array}{l}-0.384 * * * \\
(-6.09)\end{array}$ & $\begin{array}{l}-0.366^{* * * *} \\
(-6.59)\end{array}$ & $\begin{array}{l}-0.436 * * * \\
(-6.00)\end{array}$ & $\begin{array}{l}-0.383^{* * *} \\
(-6.51)\end{array}$ & $\begin{array}{l}-0.384 * * * \\
(-6.72)\end{array}$ & $\begin{array}{l}-0.398 * * * \\
(-6.11)\end{array}$ & $\begin{array}{l}-0.360 * * * \\
(-5.99)\end{array}$ & $\begin{array}{l}-0.388^{* * *} \\
(-6.57)\end{array}$ & $\begin{array}{l}-0.360 \text { *** } \\
(-5.99)\end{array}$ \\
\hline reer & $\begin{array}{l}-0.015 \\
(-0.60)\end{array}$ & $\begin{array}{l}-0.015 \\
(-0.60)\end{array}$ & $\begin{array}{l}-0.007 \\
(-0.30)\end{array}$ & $\begin{array}{l}-0.017 \\
(-0.68)\end{array}$ & $\begin{array}{l}-0.012 \\
(-0.45)\end{array}$ & $\begin{array}{l}-0.015 \\
(-0.58)\end{array}$ & $\begin{array}{l}-0.014 \\
(-0.69)\end{array}$ & $\begin{array}{l}-0.015 \\
(-0.61)\end{array}$ & $\begin{array}{l}-0.016 \\
(-0.61)\end{array}$ & $\begin{array}{l}-0.015 \\
(-0.61)\end{array}$ \\
\hline consumption & $\begin{array}{l}0.391^{* *} \\
(2.70)\end{array}$ & $\begin{array}{l}0.391 \text { ** } \\
(2.69)\end{array}$ & $\begin{array}{l}0.435 * * * \\
(3.33)\end{array}$ & $\begin{array}{l}0.368^{* *} \\
(2.56)\end{array}$ & $\begin{array}{l}0.399^{* *} \\
(2.79)\end{array}$ & $\begin{array}{l}0.390^{* *} \\
(2.87)\end{array}$ & $\begin{array}{l}0.420^{* * * *} \\
(3.29)\end{array}$ & $\begin{array}{l}0.393 \text { ** } \\
(2.56)\end{array}$ & $\begin{array}{l}0.378^{* *} \\
(2.61)\end{array}$ & $\begin{array}{l}0.399 * * \\
(2.63)\end{array}$ \\
\hline unemployment & $\begin{array}{l}0.236^{*} \\
(1.96)\end{array}$ & $\begin{array}{l}0.236^{*} \\
(1.93)\end{array}$ & $\begin{array}{l}0.312^{* *} \\
(2.75)\end{array}$ & $\begin{array}{l}0.292 * * * \\
(2.91)\end{array}$ & $\begin{array}{l}0.273^{* *} \\
(2.09)\end{array}$ & $\begin{array}{l}0.236^{*} \\
(1.86)\end{array}$ & $\begin{array}{l}0.267^{*} \\
(1.85)\end{array}$ & $\begin{array}{l}0.248^{*} \\
(1.84)\end{array}$ & $\begin{array}{l}0.238^{*} \\
(1.93)\end{array}$ & $\begin{array}{l}0.246^{*} \\
(1.86)\end{array}$ \\
\hline $\begin{array}{l}\text { Adjusted } \mathrm{R}^{2} \\
\text { Observations }\end{array}$ & $\begin{array}{l}0.775 \\
68\end{array}$ & $\begin{array}{l}0.771 \\
68\end{array}$ & $\begin{array}{l}0.799 \\
68\end{array}$ & $\begin{array}{l}0.785 \\
68\end{array}$ & $\begin{array}{l}0.784 \\
68\end{array}$ & $\begin{array}{l}0.771 \\
68\end{array}$ & $\begin{array}{l}0.798 \\
68\end{array}$ & $\begin{array}{l}0.774 \\
68\end{array}$ & $\begin{array}{l}0.771 \\
68\end{array}$ & $\begin{array}{l}0.774 \\
68\end{array}$ \\
\hline \multicolumn{11}{|l|}{ Specification tests } \\
\hline $\mathrm{N}_{1}$ & 0.000 & 0.000 & 0.000 & 0.000 & 0.000 & 0.000 & 0.000 & 0.000 & 0.000 & 0.000 \\
\hline $\mathrm{N}_{2}$ & 0.005 & 0.003 & 0.023 & 0.036 & 0.013 & 0.029 & 0.016 & 0.015 & 0.051 & 0.015 \\
\hline $\mathrm{N}_{3}$ & 0.042 & 0.048 & 0.227 & 0.018 & 0.050 & 0.071 & 0.007 & 0.094 & 0.043 & 0.106 \\
\hline $\mathrm{N}_{4}$ & 0.208 & 0.199 & 0.365 & 0.418 & 0.405 & 0.228 & 0.391 & 0.305 & 0.321 & 0.300 \\
\hline $\mathrm{N}_{5}$ & 0.000 & 0.000 & 0.000 & 0.000 & 0.000 & 0.000 & 0.000 & 0.000 & 0.000 & 0.000 \\
\hline $\mathrm{N}_{6}$ & 0.000 & 0.000 & 0.001 & 0.000 & 0.000 & 0.000 & 0.001 & 0.039 & 0.021 & 0.040 \\
\hline
\end{tabular}




\section{CESifo Working Paper Series}

for full list see www.cesifo-group.org/wp

(address: Poschingerstr. 5, 81679 Munich, Germany, office@cesifo.de)

2789 Sebastian G. Kessing, Federalism and Accountability with Distorted Election Choices, September 2009

2790 Daniel Gros, Global Welfare Implications of Carbon Border Taxes, September 2009

2791 Louis N. Christofides, Michael Hoy and Ling Yang, The Gender Imbalance in Participation in Canadian Universities (1977-2005), September 2009

2792 Jan K. Brueckner and Robert W. Helsley, Sprawl and Blight, September 2009

2793 Vidar Christiansen and Stephen Smith, Externality-correcting Taxes and Regulation, September 2009

2794 John Beirne, Guglielmo Maria Caporale, Marianne Schulze-Ghattas and Nicola Spagnolo, Global and Regional Spillovers in Emerging Stock Markets: A Multivariate GARCH-in-mean Analysis, September 2009

2795 Rüdiger Pethig and Frieder Kolleß, Asymmetric Capital-Tax Competition, Unemployment and Losses from Capital Market Integration, September 2009

2796 Ngo Van Long, Horst Raff and Frank Stähler, Innovation and Trade with Heterogeneous Firms, September 2009

2797 Margit Osterloh and Bruno S. Frey, Research Governance in Academia: Are there Alternatives to Academic Rankings?, September 2009

2798 Thiess Buettner and Clemens Fuest, The Role of the Corporate Income Tax as an Automatic Stabilizer, September 2009

2799 Annette Alstadsæter, Measuring the Consumption Value of Higher Education, September 2009

2800 Peter Friedrich, Chang Woon Nam and Janno Reiljan, Local Fiscal Equalization in Estonia: Is a Reform Necessary?, September 2009

2801 Evžen Kočenda and Jan Hanousek, State Ownership and Control in the Czech Republic, September 2009

2802 Michael Stimmelmayr, Wage Inequality in Germany: Disentangling Demand and Supply Effects, September 2009

2803 Biswa N. Bhattacharyay, Towards a Macroprudential Surveillance and Remedial Policy Formulation System for Monitoring Financial Crisis, September 2009 
2804 Margarita Katsimi, Sarantis Kalyvitis and Thomas Moutos, "Unwarranted" Wage Changes and the Return on Capital, September 2009

2805 Christian Lessmann and Gunther Markwardt, Aid, Growth and Devolution, September 2009

2806 Bas Jacobs and Dirk Schindler, On the Desirability of Taxing Capital Income to Reduce Moral Hazard in Social Insurance, September 2009

2807 Hans Gersbach and Noemi Hummel, Climate Policy and Development, September 2009

2808 David E. Wildasin, Fiscal Competition for Imperfectly-Mobile Labor and Capital: A Comparative Dynamic Analysis, September 2009

2809 Johan Eyckmans and Cathrine Hagem, The European Union's Potential for Strategic Emissions Trading through Minimal Permit Sale Contracts, September 2009

2810 Ruediger Bachmann and Christian Bayer, The Cross-section of Firms over the Business Cycle: New Facts and a DSGE Exploration, October 2009

2811 Slobodan Djajić and Michael S. Michael, Temporary Migration Policies and Welfare of the Host and Source Countries: A Game-Theoretic Approach, October 2009

2812 Devis Geron, Social Security Incidence under Uncertainty Assessing Italian Reforms, October 2009

2813 Max-Stephan Schulze and Nikolaus Wolf, Economic Nationalism and Economic Integration: The Austro-Hungarian Empire in the Late Nineteenth Century, October 2009

2814 Emilia Simeonova, Out of Sight, Out of Mind? The Impact of Natural Disasters on Pregnancy Outcomes, October 2009

2815 Dan Kovenock and Brian Roberson, Non-Partisan 'Get-Out-the-Vote' Efforts and Policy Outcomes, October 2009

2816 Sascha O. Becker, Erik Hornung and Ludger Woessmann, Catch Me If You Can: Education and Catch-up in the Industrial Revolution, October 2009

2817 Horst Raff and Nicolas Schmitt, Imports, Pass-Through, and the Structure of Retail Markets, October 2009

2818 Paul De Grauwe and Daniel Gros, A New Two-Pillar Strategy for the ECB, October 2009

2819 Guglielmo Maria Caporale, Thouraya Hadj Amor and Christophe Rault, International Financial Integration and Real Exchange Rate Long-Run Dynamics in Emerging Countries: Some Panel Evidence, October 2009 
2820 Saša Žiković and Randall K. Filer, Hybrid Historical Simulation VaR and ES: Performance in Developed and Emerging Markets, October 2009

2821 Panu Poutvaara and Andreas Wagener, The Political Economy of Conscription, October 2009

2822 Steinar Holden and Åsa Rosén, Discrimination and Employment Protection, October 2009

2823 David G. Mayes, Banking Crisis Resolution Policy - Lessons from Recent Experience Which elements are needed for robust and efficient crisis resolution?, October 2009

2824 Christoph A. Schaltegger, Frank Somogyi and Jan-Egbert Sturm, Tax Competition and Income Sorting: Evidence from the Zurich Metropolitan Area, October 2009

2825 Natasa Bilkic, Thomas Gries and Margarethe Pilichowski, Stay in School or Start Working? - The Human Capital Investment Decision under Uncertainty and Irreversibility, October 2009

2826 Hartmut Egger and Udo Kreickemeier, Worker-Specific Effects of Globalisation, October 2009

2827 Alexander Fink and Thomas Stratmann, Institutionalized Bailouts and Fiscal Policy: The Consequences of Soft Budget Constraints, October 2009

2828 Wolfgang Ochel and Anja Rohwer, Reduction of Employment Protection in Europe: A Comparative Fuzzy-Set Analysis, October 2009

2829 Rainald Borck and Martin Wimbersky, Political Economics of Higher Education Finance, October 2009

2830 Torfinn Harding and Frederick van der Ploeg, Is Norway's Bird-in-Hand Stabilization Fund Prudent Enough? Fiscal Reactions to Hydrocarbon Windfalls and Graying Populations, October 2009

2831 Klaus Wälde, Production Technologies in Stochastic Continuous Time Models, October 2009

2832 Biswa Bhattacharyay, Dennis Dlugosch, Benedikt Kolb, Kajal Lahiri, Irshat Mukhametov and Gernot Nerb, Early Warning System for Economic and Financial Risks in Kazakhstan, October 2009

2833 Jean-Claude Trichet, The ECB's Enhanced Credit Support, October 2009

2834 Hans Gersbach, Campaigns, Political Mobility, and Communication, October 2009

2835 Ansgar Belke, Gunther Schnabl and Holger Zemanek, Real Convergence, Capital Flows, and Competitiveness in Central and Eastern Europe, October 2009 
2836 Bruno S. Frey, Simon Luechinger and Alois Stutzer, The Life Satisfaction Approach to Environmental Valuation, October 2009

2837 Christoph Böhringer and Knut Einar Rosendahl, Green Serves the Dirtiest: On the Interaction between Black and Green Quotas, October 2009

2838 Katarina Keller, Panu Poutvaara and Andreas Wagener, Does Military Draft Discourage Enrollment in Higher Education? Evidence from OECD Countries, October 2009

2839 Giovanni Cespa and Xavier Vives, Dynamic Trading and Asset Prices: Keynes vs. Hayek, October 2009

2840 Jan Boone and Jan C. van Ours, Why is there a Spike in the Job Finding Rate at Benefit Exhaustion?, October 2009

2841 Andreas Knabe, Steffen Rätzel and Stephan L. Thomsen, Right-Wing Extremism and the Well-Being of Immigrants, October 2009

2842 Andrea Weber and Christine Zulehner, Competition and Gender Prejudice: Are Discriminatory Employers Doomed to Fail?, November 2009

2843 Hadi Salehi Esfahani, Kamiar Mohaddes and M. Hashem Pesaran, Oil Exports and the Iranian Economy, November 2009

2844 Ruediger Bachmann and Christian Bayer, Firm-Specific Productivity Risk over the Business Cycle: Facts and Aggregate Implications, November 2009

2845 Guglielmo Maria Caporale, Burcu Erdogan and Vladimir Kuzin, Testing for Convergence in Stock Markets: A Non-Linear Factor Approach, November 2009

2846 Michèle Belot and Jan Fidrmuc, Anthropometry of Love - Height and Gender Asymmetries in Interethnic Marriages, November 2009

2847 Volker Nitsch and Nikolaus Wolf, Tear Down this Wall: On the Persistence of Borders in Trade, November 2009

2848 Jan K. Brueckner and Stef Proost, Carve-Outs Under Airline Antitrust Immunity, November 2009

2849 Margarita Katsimi and Vassilis Sarantides, The Impact of Fiscal Policy on Profits, November 2009 